
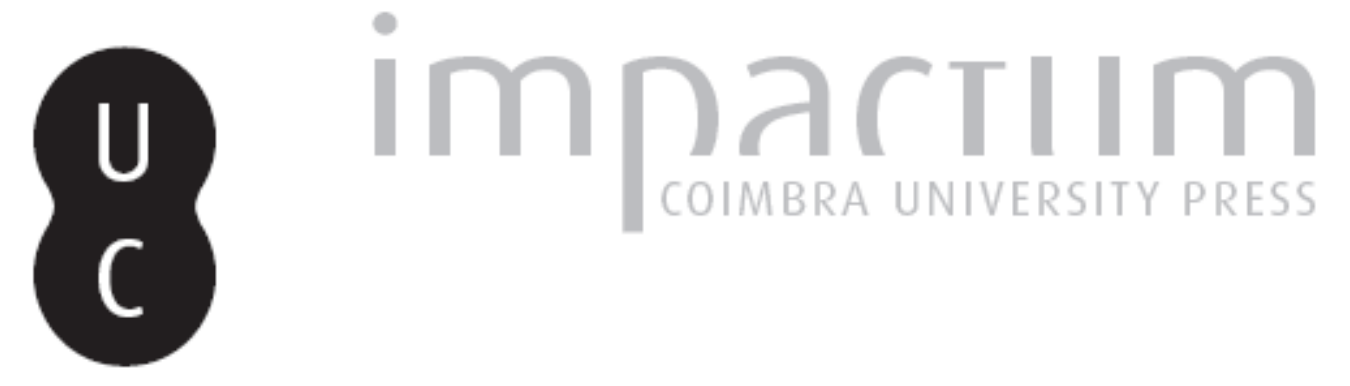

\title{
Evolução histórica da teoria hermenêutica: do formalismo do século XVIII ao pós- positivismo
}

\author{
Autor(es): $\quad$ Rocha, Sergio André \\ Publicado por: Universidade Católica de Petrópolis \\ URL \\ persistente: \\ URI:http://hdl.handle.net/10316.2/33902 \\ DOI: \\ DOI:http://dx.doi.org/10.14195/2175-0947_1-1_4
}

Accessed : $\quad$ 26-Apr-2023 10:04:16

A navegação consulta e descarregamento dos títulos inseridos nas Bibliotecas Digitais UC Digitalis, UC Pombalina e UC Impactum, pressupõem a aceitação plena e sem reservas dos Termos e Condições de Uso destas Bibliotecas Digitais, disponíveis em https://digitalis.uc.pt/pt-pt/termos.

Conforme exposto nos referidos Termos e Condições de Uso, o descarregamento de títulos de acesso restrito requer uma licença válida de autorização devendo o utilizador aceder ao(s) documento(s) a partir de um endereço de IP da instituição detentora da supramencionada licença.

Ao utilizador é apenas permitido o descarregamento para uso pessoal, pelo que o emprego do(s) título(s) descarregado(s) para outro fim, designadamente comercial, carece de autorização do respetivo autor ou editor da obra.

Na medida em que todas as obras da UC Digitalis se encontram protegidas pelo Código do Direito de Autor e Direitos Conexos e demais legislação aplicável, toda a cópia, parcial ou total, deste documento, nos casos em que é legalmente admitida, deverá conter ou fazer-se acompanhar por este aviso.

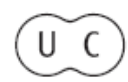



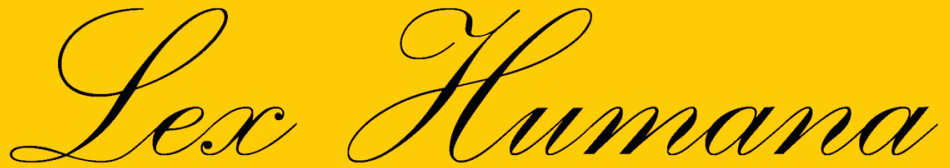

Revista do Programa de Pós-Graduação em Direito da UCP

ISSN(e) 2175-0947

Universidade Católica de Petrópolis Rua Benjamin Constant, 213 - Petrópolis - Centro CEP 25610-130

Tel: (24) 2244-4000 E-mail: lexhumana@ucp.br 


\section{EVOLUÇÃO HISTÓRICA DA TEORIA HERMENÊUTICA:}

\section{DO FORMALISMO DO SÉCULO XVIII AO PÓS-POSITIVISMO}

Sergio André Rocha

O propósito deste estudo é a apresentação de considerações acerca de aspectos relevantes das principais escolas hermenêuticas que se sucederam ao longo dos dois últimos séculos, com vistas a formar uma compreensão de como se apresenta a questão da interpretação jurídica hodiernamente.

1. O formalismo jurídico na Alemanha, na Inglaterra e na França

1.1. A jurisprudência dos conceitos e o formalismo jurídico alemão do Século XIX

\subsubsection{A escola histórica do direito}

O formalismo jurídico na Alemanha e a reação ao direito natural forjaram-se ao longo do século XIX, em princípio com o desenvolvimento da escola histórica do direito e posteriormente com o surgimento da jurisprudência dos conceitos.

O historicismo, que teve início com Gustav Hugo (1764 - 1844) e encontrou seu mais célebre expoente na figura de Friedrich Karl von Savigny (1779 - 1861), legou à jurisprudência dos conceitos a idéia de sistema, extremamente relevante para o seu desenvolvimento. ${ }^{1}$ Ademais, a escola histórica colocava-se em ponto de colisão com as idéias jus naturalistas, na medida em que, como destaca Norberto Bobbio, "ao direito natural a escola histórica contrapõe o direito consuetudinário, considerado como a forma genuína do direito, enquanto expressão imediata da realidade histórico social

1 Cf. LARENZ, Karl. Metodologia da Ciência do Direito. 3.ed. Tradução José Lamego. Lisboa: Fundação Calouste Gulbenkian, 1997. p. 19; GUERRA FILHO, Willis Santiago. Teoria da Ciência Jurídica. São Paulo: Saraiva, 2001. p. 31. 
e do Volksgeist". ${ }^{2}$

Todavia, o historicismo rejeitava a possibilidade de que as leis pudessem ser criadas ex nihilo pelo legislador, sendo estas, na verdade, um fenômeno histórico. ${ }^{3}$

Tal característica encontra-se relacionada com a própria fragmentação que a Alemanha ostentou até a segunda metade do Século XIX. Não havendo ainda um Estado alemão não havia a crença na prevalência de um direito posto. ${ }^{4}$

Nesse contexto se encaixa a separação feita por Savigny entre as regras de direito e os institutos jurídicos, a qual de certa forma aproxima seu historicismo da jurisprudência dos conceitos, na medida em que se sustenta que os institutos jurídicos, forjados pelo espírito do povo, ${ }^{5}$ é que devem 2 BOBBIO, Norberto. O Positivismo Jurídico: Lições de Filosofia do Direito. Tradução Márcio Pugliesi; Edson Bini; Carlos E. Rodrigues. São Paulo: Ícone, 1995. p. 53. Ver, ainda: RADBRUCH, Gustav. Filosofia do Direito. 6. ed. Tradução L. Cabral de Moncada. Coimbra: Arménio Amado, 1997. p. 64 e 65; KAUFMANN, Arthur. Filosofia del Derecho. Tradução Luis Villar Borda. Bogotá: Universidad Externado de Colombia, 1999. p. 70; ADEODATO, João Maurício. Positividade e Conceito de Direito. In: Ética e Retórica: Para uma Teoria da Dogmática Jurídica. São Paulo: Saraiva, 2002. p. 20 e 21; ROBLES, Gregorio. Introducción a la teoría del derecho. 6. ed. Barcelona: Debate, 2003. p. 137; COELHO, L. Fernando. Lógica Jurídica e Interpretação das Leis. 2. ed. Rio de Janeiro: Forense, 1981. p. 233-234.

3 Cf. ATIENZA, Manuel. El Sentido del Derecho. 2. ed. Barcelona: Ariel, 2003. p. 232; FERAZ JR., Tercio Sampaio. Introdução ao Estudo do Direito. 3. ed. São Paulo: Atlas, 2001. p. 76.

4 Cf. HESPANHA, António Manuel. Cultura Jurídica Européia: Síntese de um Milénio. Mem Martins: Europa-America, 2003. p. 270.

$5 \quad$ Cf. SAVIGNY, Friedrich Karl von. Sistema del Derecho Romano Actual. 2. ed. Tradução Jacinto Mesía; Manuel Poley. Madrid: Editorial de Góngora, [s/d]. t. I. p. 66 e 67. Conforme destaca Giorgio del Vecchio, "a 'consciência histórica do povo' é um conceito característico da escola histórica do Direito, que o derivou do historicismo filosófico de Schelling e Hegel, tanto que pode ser considerado como uma particular aplicação das doutrinas desses filósofos no campo do Direito. Segundo a escola histórica, todo povo tem um espírito, uma alma própria, que se reflete em uma numerosa série de manifestações: Moral, Direito, Arte, Linguagem, os quais são todos produtores espontâneos e imediatos do espírito popular (Volksgeist)" (DEL VECCHIO, Giorgio. Filosofia del Derecho. 9. ed. Barcelona: Bosch, 1997. p. 120 e 121). Ver também: RECASENS SICHES, Luis. Tratado General de Filosofía del Derecho. 14. ed. México: Editorial Porrúa, 1999. p. 441; 
servir de baliza para a compreensão das regras de direito, de forma que "o legislador cria a regra isolada a partir da idéia que ele formou do instituto jurídico como um todo". 6

É evidente que esses traços de aproximação não significam que o historicismo se confunda com a jurisprudência dos conceitos. De fato, considerando a gênese consuetudinária dos institutos jurídicos de Savigny, jamais se poderia ver os mesmos como conceitos. Como bem ponderam Jean-Cassien Biller e Aglaé Maryioli, “o enfoque histórico redundou em um trabalho de genealogia de conceitos que não é mais histórica, é lógica".

Outro importante legado de Savigny foi sua teoria da interpretação.

Com efeito, destacava o mestre alemão a indispensabilidade da interpretação como forma de interação entre o intérprete e o texto, ressaltando que a interpretação "é indispensável para toda aplicação da lei à vida real", de forma que esta "não está restrita, como crêem alguns, ao caso acidental de obscuridade da lei". 8

OLIVEIRA ASCENÇÃO, José de. Introdução à Ciência do Direito. 3. ed. Rio de Janeiro: Renovar, 2005. p. 163.

6 Cf. COING, Helmut. Elementos Fundamentais da Filosofia do Direito. Tradução Elisete Antoniuk. Porto Alegre: Sergio Antonio Fabris, 2002. p. 315. Nas palavras de Savigny: "A solução de um caso prático não é possível senão referindo-o a uma regra geral, que domine os casos particulares. Esta regra se chama direito, ou direito geral, ou às vezes também direito em sentido objetivo. Se manifesta sobretudo na lei, isto é, na regra promulgada pela autoridade suprema de um Estado.

Se a decisão de um caso particular é de natureza restrita e subordinada; se encontra sua raiz viva e sua força de convicção na apreciação da relação de direito, a regra jurídica e a lei, que é sua expressão, têm por base as instituições cuja natureza orgânica se mostra no conjunto mesmo de suas partes constitutivas e em seus desenvolvimentos sucessivos. Assim, pois, quando não se quer limitar-se às manifestações exteriores, mas sim penetrar a essência das coisas, reconhece-se que cada elemento da relação de direito refere-se a uma instituição que o domina e lhe serve de tipo, da mesma forma que cada decisão está dominada por uma regra e este segundo encadeamento, ligando-se ao primeiro, encontra ali a realidade e a vida" (SAVIGNY, Friedrich Karl von, Sistema del Derecho Romano Actual, [s/d], t. I, p. 81).

7 BILLIER, Jean-Cassien; MARYIOLI, Aglaé. História da Filosofia do Direito. Barueri: Manole, 2005. p. 191.

8 SAVIGNY, Friedrich Karl von, Sistema del Derecho Romano Actual, [s/d], t. I, p. 184. 
Para Savigny, a interpretação seria "a reconstrução do pensamento contido na lei", podendo a mesma ser decomposta em partes constitutivas, as quais correspondem aos seus quatro elementos (note-se que Savigny fala em elementos e não em métodos): gramatical, lógico, histórico e sistemático. ${ }^{9}$

Esses seriam os elementos constitutivos de todo e qualquer processo interpretativo, não se podendo escolher um deles em detrimento dos demais, sendo o exame de todos os elementos indispensável para a interpretação da lei. ${ }^{10}$

Diante do exposto, é possível afirmar que a escola histórica do direito legou à jurisprudência dos conceitos alguns dos fundamentos sobre os quais esta se desenvolveu: seu caráter positivo, ${ }^{11}$ sua sistematicidade ${ }^{12}$ e a própria busca de justificação do mais específico no mais geral. ${ }^{13}$

\subsection{A jurisprudência dos conceitos}

Diante do exposto, tem-se que a jurisprudência dos conceitos partiu de alguns alicerces lançados pela escola história, os quais foram trabalhados por Friedrich Puchta (1798-1846), discípulo de Savigny, para o desenvolvimento de sua genealogia dos conceitos. ${ }^{14}$

Os principais expoentes da jurisprudência dos conceitos foram o 9 SAVIGNY, Friedrich Karl von, Sistema del Derecho Romano Actual, [s/d], t. I, p. 187.

10 SAVIGNY, Friedrich Karl von, Sistema del Derecho Romano Actual, [s/d], t. I, p. 189.

11 Cf. ALCHOURRÓN, Carlos E. Introducción a la Metodología de las Ciencias Jurídicas y Sociales. Buenos Aires: Editorial Astrea, 2002. p. 90.

12 Cf. HESPANHA, António Manuel, Cultura Jurídica Européia: Síntese de um Milénio, 2003, p. 274; ANDRADE, José Maria Arruda de. Interpretação da Norma Tributária. São Paulo: MP Editora, 2006. p. 47.

13 Mencionando a relação entre a escola histórica e a jurisprudência dos conceitos, ver: DEL VECCHIO, Giorgio, Filosofia del Derecho, 1997, p. 121; LARENZ, Karl, Metodologia da Ciência do Direito, 1997, p. 19; ATIENZA, Manuel, El Sentido del Derecho, 2003, p. 233; FERNÁNDEZ-LARGO, Antonio Osuna. La Hermenéutica Jurídica de Hans-Georg Gadamer. Valladolid: Secretariado de Publicaciones, 1992. p. 20.

14 Cf. FERAZ JR., Tercio Sampaio, Introdução ao Estudo do Direito, 2001, p. 77; LARENZ, Karl, Metodologia da Ciência do Direito, 1997, p. 23; HESPANHA, António Manuel, Cultura Jurídica Européia: Síntese de um Milénio, 2003, p. 274. 
supracitado Friedrich Puchta e Rudolf von Ihering (1818-1892), embora este último tenha posteriormente tornado-se um de seus maiores opositores. ${ }^{15}$

A jurisprudência dos conceitos reflete uma teoria jurídica lógicoracionalista, na medida em que atribui aos conceitos jurídicos a possibilidade de enclausurar o direito, sendo desnecessária qualquer valoração para a compreensão das regras jurídicas, mas sim a sua recondução a conceitos superiores. ${ }^{16}$

Tem-se aqui o cerne da genealogia dos conceitos de Puchta, explicitada por Karl Larenz nos seguintes termos:

A idéia de Puchta é a seguinte: cada conceito superior autoriza certas afirmações (por ex., o conceito de direito subjetivo é de que se trata de 'um poder sobre um objeto'); por conseguinte, se um conceito inferior se subsumir ao superior, valerão para ele 'forçosamente' todas as afirmações que se fizerem sobre o conceito superior (para o crédito, como espécie de direito subjetivo, significa isto, por ex., que ele é 'um poder sobre um objeto que esteja sujeito à vontade do credor e que se poderá então vislumbrar, ou na pessoa do devedor, ou no comportamento devido por este último'). A 'genealogia dos conceitos' ensina, portanto, que o conceito supremo, de que se deduzem todos os

15 Sobre a teoria conceitualista de Ihering, ver: HART, H. L. A. Jhering's Heaven of Concepts. In: Essays in Jurisprudence and Philosophy. New York: Oxford University Press, 2001. p. 265-277.

16 Nas palavras de Arthur Kaufmann, "traço característico da jurisprudência dos conceitos, que não tem de estar, forçosamente, dependente do positivismo, é a dedução de princípios jurídicos a partir de meros conceitos; por exemplo, do conceito de 'pessoa jurídica' retira-se a conseqüência de que a pessoa jurídica, enquanto 'pessoa', é suscetível de ser ofendida e de ser incriminada. Os conceitos servem de fonte de conhecimento. É nesse ontologismo, de acordo com o qual a existência procede da essência, que repousa a famosa demonstração ontológica de Deus: do conceito do 'ser mais perfeito' resultaria necessariamente a sua existência (caso contrário ele não seria perfeito)" (KAUFMANN, Arthur. A problemática da filosofia do direito ao longo da história. In: KAUFMANN, Arthur; ACEDER, W. (Ufrgs.). Introdução à Filosofia do Direito e à Teoria do Direito Contemporâneas. Tradução Marcos Keel. Lisboa: Fundação Calouste Gulbenkian, 2002. p. 168). 
outros, codetermina os restantes através do seu conteúdo. Porém, de onde precede o conteúdo desse conceito supremo? Um conteúdo terá ele que possuir, se é que dele se podem extrair determinados enunciados, e esse conteúdo não deve proceder dos conceitos dele inferidos, sob pena de ser tudo isto um círculo vicioso. Segundo Puchta, este conteúdo procede da filosofia do Direito: assim, consegue um ponto de partida seguro com que construir dedutivamente todo o sistema e inferir novas proposições jurídicas. ${ }^{17}$

Partindo-se dessas idéias, é possível compreender a jurisprudência dos conceitos como uma doutrina formalista, segundo a qual a atividade de interpretação/aplicação do direito dar-se-ia de forma lógico-dedutiva, mediante a subsunção de conceitos inferiores a conceitos superiores. ${ }^{18}$

A genealogia dos conceitos implica um sistema jurídico organizado de forma piramidal, de forma que os conceitos inferiores se legitimam na medida em que podem ser reconduzidos subsuntivamente a conceitos superiores, até se chegar ao conceito supremo que, segundo Puchta, procederia da filosofia. ${ }^{19}$

Assim, percebe-se que a validade dos conceitos inferiores é definida em termos puramente lógicos, sem qualquer implicação axiológica. Conforme salienta Helmut Coing, "com isto, tanto o trabalho da ciência como o do juiz, torna-se uma atividade puramente lógica: os interesses e valores em jogo não mais aparecem". ${ }^{20}$

Na lição de Oliveira Ascenção, decorrência da forma de pensar conceitualista é a idéia de completude do sistema jurídico, de modo que "por

17 LARENZ, Karl, Metodologia da Ciência do Direito, 1997, p. 25.

18 Ver: HESPANHA, António Manuel, Cultura Jurídica Européia: Síntese de um Milénio, 2003, p. 283; ANDRADE, José Maria Arruda de, Interpretação da Norma Tributária, 2006, p. 48.

19 Cf. LARENZ, Karl, Metodologia da Ciência do Direito, 1997, p. 25.

20 COING, Helmut, Elementos Fundamentais da Filosofia do Direito, 2002, p. 318. Para Arthur Kaufmann, "o método da jurisprudência dos conceitos serviu aos seus representantes para provar que a lei seria fecunda por si mesma, sem recurso às situações da vida" (KAUFMANN, Arthur. A problemática da filosofia do direito ao longo da história, 2002, p. 168). 
processos lógicos, o jurista extrairia do sistema sempre a regra adequada para regular uma situação. Pode aparentemente essa regra faltar e existir uma lacuna; mas no fundo toda a regra estará ao menos implícita no sistema". ${ }^{21}$

Aspecto interessante do formalismo alemão do Século XIX é que o mesmo desenvolveu-se antes que a Alemanha tivesse concretizado sua codificação, o que somente viria a acontecer com a edição do Código Civil Alemão que entrou em vigor no ano de 1900.

Como se sabe, o próprio Savigny era um opositor da ideia da codificação na Alemanha, o que deu azo à célebre contenda com Anton Justus Friedrich Thibaut (1772-1840), defensor do esforço codificante. ${ }^{22}$

Tal fato já denuncia um traço diferencial entre a jurisprudência dos conceitos alemã e a escola da exegese francesa, a ser examinada a seguir. Embora tratem-se de duas escolas formalistas, o formalismo alemão forjouse com base na consciência histórica e na lógica conceitual, enquanto o formalismo exegético francês tinha como ponto de partida um monumento jurídico-positivo: o Código Civil Napoleônico de 1804.

\subsection{A escola da exegese e o formalismo jurídico francês do Século}

21

OLIVEIRA ASCENÇÃO, José de, Introdução à Ciência do Direito, 2005, p. 458. Também nesse sentido: HECK, Philipp. El Problema de la Creación del Derecho. Tradução Manuel Entenza. Granada: Comares, 1999. p. 35; FERAZ JR., Tercio Sampaio, Introdução ao Estudo do Direito, 2001, p. 79. Os principais traços da jurisprudência dos conceitos encontram-se bem sintetizados nas seguintes palavras de Maria Margarida Lacombe Camargo: "A atividade científica consistia em estabelecer conceitos bem definidos, que pudessem garantir segurança às relações jurídicas, uma vez diminuída a ambigüidade e a vaguedade dos termos legais. E foi por meio da elaboração de conceitos gerais, posicionados na parte superior da figura de uma pirâmide, capazes de conter e dar origem a outros conceitos de menor alcance numa união total, perfeita e acabada, que o direito alcançou seu maior grau de abstração e autonomia como campo de conhecimento. Esse alto grau de racionalidade deu origem ao 'dogma da subsunção' que irá se impor no século seguinte. O direito era tido como fruto de um desdobramento lógico-dedutivo entre premissas capazes de gerar por si sós uma conclusão que servisse de juízo concreto para cada decisão. [...]" (CAMARGO, Maria Margarida Lacombe. Hermenêutica Jurídica e Argumentação: Uma Contribuição ao Estudo do Direito. 2. ed. Rio de Janeiro: Renovar, 2001. p. 87).

22 Sobre o movimento pela codificação de Thibaut e sua contenda com Savigny, ver: BOBBIO, Norberto, O Positivismo Jurídico: Lições de Filosofia do Direito, 1995, p. 53-62. 
XIX

A escola da exegese francesa desenvolveu-se no século XIX principalmente a partir da edição do Código Civil Francês de 1804, o Código de Napoleão, tendo entre seus expoentes Jean Ch. F. Demolombe, Troplong, Alexandre Duranton, Proudhon, Charles Aubry, Frédéric Charles Rau e Pothier, entre outros juristas franceses. ${ }^{23}$

Como visto, ao contrário da jurisprudência dos conceitos, o exegetismo francês representou um formalismo legalista, na medida em que, tendo por base a magnífica obra legislativa que foi o Código de Napoleão, pensavam os juristas franceses da época ser possível encontrar, no texto da lei, respostas para todas as controvérsias surgidas no âmbito do convívio social. $^{24}$

Com isso, relegou-se ao intérprete/aplicador do direito uma tarefa 23 Nas palavras de Maria Helena Diniz, "a escola da exegese reuniu a quasetotalidade dos juristas franceses [...] durante a época da codificação do direito civil francês e o tempo que se sucedeu à promulgação do célebre Código de Napoleão" (DINIZ, Maria Helena. Compêndio de Introdução à Ciência do Direito. 5. ed. São Paulo: Saraiva, 1993. p. 47).

24 Segundo Maria Margarida Lacombe Camargo, "havia uma pretensão de se encontrar na lei a resposta para todos os conflitos. De fato, em um momento de pouca complexidade social e progresso em lenta evolução, o código napoleônico conseguiu manter-se praticamente inalterado até o final do século, e com ele as propostas da escola da exegese" (CAMARGO, Maria Margarida Lacombe, Hermenêutica Jurídica e Argumentação: Uma Contribuição ao Estudo do Direito, 2001, p. 87). António Manuel Hespanha destaca que diante dos códigos napoleônicos "não podiam valer quaisquer outras fontes de direito. Não o direito doutrinal, racional, suprapositivo, porque ele tinha sido incorporado nos códigos, pelo menos na medida em que isso tinha sido aceite pela vontade popular. Não o direito tradicional, porque a Revolução tinha cortado com o passado e instituído uma ordem política e jurídica nova. Não o direito jurisprudencial, porque aos juízes não competia o poder de estabelecer o direito (poder legislativo), mas apenas o de o aplicar (poder judicial). A lei - nomeadamente, esta lei compendiada e sistematizada em códigos - adquiria, assim, o monopólio da manifestação do direito. A isto se chamou legalismo ou positivismo legal (Gesetzpositivismus)" (HESPANHA, António Manuel, Cultura Jurídica Européia: Síntese de um Milénio, 2003, p. 268-269). Ver, ainda: SALDANHA, Nelson. Da Teologia à Metodologia: Secularização e crise do pensamento jurídico. 2. ed. Belo Horizonte: Del Rey, 2005. p. 77; RECASÉNS SICHES, Luis. Panorama del Pensamiento Jurídico en el Siglo XX. México: Porrua, 1963. t. I. p. 31. 
meramente mecânica de aplicação das normas codificadas, ${ }^{25}$ as quais sequer deveriam ser objeto de interpretação. Conforme destaca García Máynez, "a interpretação é, pois, partindo desse ponto de vista, esclarecimento dos textos, não interpretação do direito. Ignoro o direito civil - exclamava Bugnet - "só conheço o Código de Napoleão"'. ${ }^{26}$

Esse aspecto foi ressaltado por François Gény, crítico da escola exegética. Segundo o jurista francês, principalmente por obra dos estudiosos que se desenvolveram após a vigência do Código houve uma importante mudança no papel assumido pelo intérprete. Em suas palavras: ${ }^{27}$

Daí a regra insculpida no artigo $4^{\circ}$ do Código, segundo a qual os juízes não poderiam deixar de julgar um caso particular ao argumento de que a lei seria obscura ou omissa, chegando-se, portanto, ao dogma da completude do ordenamento jurídico, o qual deve conter respostas para todas as perguntas. ${ }^{28}$

25 Cf. AFTALIÓN, Enrique R.; OLANO, Fernando García; VILANOVA, José. Introducción al Derecho. 7. ed. Buenos Aires: La Ley, [196-]. p. 804; COELHO, L. Fernando, Lógica Jurídica e Interpretação das Leis, 1981, p. 226. 26 GARCÍA MÁYNEZ, Eduardo. Introducción al Estudio del Derecho. 53. ed. México: Editorial Porrúa, 2002. p. 334. Nas palavras de Luiz Alberto Warat, "a concepção que orienta o método exegético, tanto como a que inspira o método gramatical, se baseia na idéia de que as leis conformam um universo significativo autosuficiente, do qual se pode inferir por atos de derivação racional as soluções para todo o tipo de conflito jurídico. Fundamentalmente supõe a figura de um juiz neutro, mecânico, não criativo. É uma crença mítica, plasmada em uma expressão retórica reiterativa, que ficou sempre no plano conceitual" (WARAT, Luiz Alberto. Introdução Geral ao Direito. Porto Alegre: Sergio Antonio Fabris Editor, 1994. v. I. p. 69-70). Ver, também: BERGEL, Jean-Louis. Teoria Geral do Direito. Tradução Maria Ermantina Galvão. São Paulo, Martins Fontes, 2001. p. 325. 27 GÉNY, François. Método de Interpretación y Fuentes en Derecho Privado Positivo. 2. ed. Madrid: Editorial Reus, 1925. p. 23. Nesse sentido, ver também: BONNECASE, Julien. Science du Droit et Romantisme. Paris: Librarie du Recueil Sirey, 1928. p. 9-13.

28 Como observa Chaïm Perelman, "o artigo 4 do Código de Napoleão, ao proclamar que o juiz não pode recusar-se a julgar sob pretexto do silêncio, da obscuridade ou da insuficiência da lei, obriga-o a tratar o sistema de direito como completo, sem lacunas, como coerente, sem antinomias e como claro, sem ambigüidades que dêem azo a interpretações diversas. Somente diante de um sistema assim é que o papel do juiz seria conforme à missão que lhe cabe, a de determinar os fatos do processo e daí extrair as conseqüências jurídicas que se impõem, sem colaborar ele próprio na elaboração da lei. Foi nesta perspectiva 
Norberto Bobbio, partindo das lições de Bonnecase, sintetizou as principais características da escola da exegese nos seguintes termos: (a) inversão das relações tradicionais entre direito natural e direito positivo, reconhecendo-se a existência de princípios pré-positivos, mas sustentandose que os mesmos são irrelevantes para o jurista enquanto não positivados; (b) defesa de uma concepção estatal do direito, de modo que somente seriam jurídicas as regras postas pela organização do Estado; (c) defesa de uma teoria subjetivista da interpretação, no sentido de que se deveria buscar a revelação da vontade do legislador contida no texto legal; (d) apego à literalidade do texto legal; e (e) apego ao princípio da autoridade, com o que se atribuía relevância não só ao texto do código, mas também às lições de seus primeiros comentadores. ${ }^{29}$

\subsection{A escola analítica e o formalismo jurídico inglês do Século XIX}

Paralelamente à escola da exegese francesa, desenvolveu-se teoria jurídica semelhante na Inglaterra do Século XIX, a qual ficou conhecida como escola analítica e teve em John Austin (1790-1859) seu principal expoente. $^{30}$

Todavia, embora Austin seja a principal figura da escola analítica, não é possível examinar o formalismo inglês desse período sem mencionar a pessoa de Jeremy Bentham (1748-1832), cujas idéias influenciaram o pensamento do primeiro.

Em primeiro lugar, Jeremy Bentham era um crítico da common law e um entusiasta da codificação e da legislação. Sobre esse ponto, é arguta a seguinte passagem de Norberto Bobbio, ao comparar as visões alemã, francesa e inglesa sobre a codificação do direito:

Observamos o curioso destino da idéia da codificação: dela não houve vigência na Alemanha

que os juristas da escola da exegese se empenharam em seu trabalho, procurando limitar o papel do juiz ao estabelecimento dos fatos e à sua subsunção sob os termos da lei" (PERELMAN, Chaïm. Lógica Jurídica. Tradução Vergínia K. Pupi. São Paulo: Martins Fontes, 2000. p. 34-35).

29 BOBBIO, Norberto, O Positivismo Jurídico: Lições de Filosofia do Direito, 1995, p. 84-89.

30 Cf. REALE, Miguel. Filosofia do Direito. 19. ed. São Paulo: Saraiva, 2002. p. 417-418. 
(no período histórico por nós examinado), porque os homens cultos que a ela eram contrários (principalmente Savigny, que podemos chamar de teórico da anticodificação) conseguiram fazer prevalecer seu ponto de vista; na França houve codificação sem ter havido uma teoria da codificação (os juristas da Revolução propuseram de fato a codificação sem, entretanto, teorizála; e Montesquieu, o maior filósofo do direito do iluminismo francês, não pode, com certeza, ser considerado um teórico da codificação); na Inglaterra, pelo contrário, onde já no século XVII existiu o maior teórico da onipotência do legislador (Thomas Hobbes), não houve a codificação, mas foi elaborada a mais ampla teoria da codificação, a de Jeremy Bentham, chamado exatamente de o "Newton da legislação". ${ }^{31}$

Ademais, além de defensor da legislação, Jeremy Bentham, com seu princípio da utilidade, impunha sobre o direito e demais relações sociais uma relatividade moral que o opunha ao jusnaturalismo.

Tal princípio da utilidade parte da idéia de que a humanidade é guiada por duas grandes forças: sofrimento e prazer, de forma que os indivíduos agiriam sempre em busca de evitar o sofrimento e maximizar o prazer. ${ }^{32}$

Embora Bentham fosse um entusiasta da legislação, vê-se que seu 31 BOBBIO, Norberto, O Positivismo Jurídico: Lições de Filosofia do Direito, 1995, p. 91.

32 Em suas palavras: "A natureza colocou a humanidade sob o governo de dois mestres soberanos, sofrimento e prazer. Cabe a eles determinar o que devemos fazer. De um lado, os standards de certo e errado e de outro, a cadeia de causas e efeitos, estão presos ao seu trono. Sofrimento e prazer nos governam em tudo o que fazemos, em tudo o que falamos, em tudo o que pensamos: todo esforço que podemos fazer para afastar nossa sujeição servirá apenas para confirmá-la. Em palavras um homem pode pretender abjurar seu império, mas em realidade ele permanecerá sujeito a eles todo o tempo. O princípio da utilidade reconhece tal sujeição e assume-a como sendo o fundamento de um sistema cujo objeto é erguer a fábrica da felicidade pelas mãos da razão e da lei" (BENTHAM, Jeremy. The Principles of Morals and Legislation. New York: Prometheus Books, [s/d]. p. 1 e 2). 
utilitarismo não era comparável às posições formalistas da jurisprudência dos conceitos e da escola da exegese. Tanto que Bobbio chega a afirmar que, em parte, as idéias de Bentham se aproximam da jurisprudência dos interesses,${ }^{33}$ a ser estudada mais adiante.

O ideário de Jeremy Bentham influenciou o desenvolvimento da escola analítica que teve em John Austin seu maior expoente. ${ }^{34}$

Traço importante dessa escola é a separação do direito positivo das demais ordens normativas, como a moral. Conforme Angel Latorre, "Austin considera, em primeiro lugar, que se deve distinguir o direito positivo de outros tipos de normas, como os usos sociais ou outros preceitos independentes daquele, que se considera o único verdadeiro direito". ${ }^{35}$

Trazendo à colação as palavras do próprio Austin:

Leis propriamente ditas, ou propriamente assim denominadas, são comandos; leis que não são comandos são leis impróprias ou impropriamente assim denominadas. Leis propriamente ditas juntamente com as leis impróprias, podem ser dividas nas quatro espécies a seguir:

1. Leis divinas ou leis de Deus: ou seja, leis estabelecidas por Deus para as suas criaturas humanas.

2. Leis positivas: ou seja, leis que são simplesmente e estritamente assim denominadas e que compõem a matéria apropriada da teoria jurídica geral e particular.

3. Moral positiva, regras de moralidade positiva ou regras morais positivas.

4. Leis em sentido metafórico ou figurativo. ${ }^{36}$

Tal finalidade é verificada no próprio título de seu trabalho principal, 33 BOBBIO, Norberto, O Positivismo Jurídico: Lições de Filosofia do Direito, 1995, p. 98.

34 Cf. ATIENZA, Manuel, El Sentido del Derecho, 2003, p. 234.

35 LATORRE, Angel. Introdução ao Direito. Tradução Manuel de Alarcão. Coimbra: Almedina, 2002. p. 157.

36 AUSTIN, John. The Province of Jurisprudence Determined. New York: Prometheus Books, [s/d]. p. 1. 
The Province of Jurisprudence Determined, que pode ser traduzido como A Determinação do Campo do Direito. Segundo Austin, seu objetivo era "distinguir o direito positivo (o verdadeiro tema do direito) dos objetos ora enumerados, objetos com os quais aquele está ligado apenas por semelhança ou analogia". ${ }^{37}$

Deixando de lado as leis divinas, para Austin apenas os comandos compunham o direito positivo, devendo-se entender por comando uma ordem cujo descumprimento é seguido de uma conseqüência (sanção) negativa para o inadimplente. ${ }^{38}$

Assim, as regras morais quedam-se fora do campo do jurídico, compondo o que Austin denomina moralidade positiva. São chamadas morais para que sejam distinguidas das normas jurídicas e são denominadas positivas, para que não sejam confundidas com as leis divinas. ${ }^{39}$

\section{Movimentos de contestação ao formalismo}

\subsection{François Gény e a livre investigação científica}

Ainda no curso do Século XIX as escolas formalistas francesa e alemã foram objeto de crítica.

Na França, a Escola da Exegese foi alvo de contestação por François Gény (1861-1959) e sua doutrina da livre pesquisa do direito. Na Alemanha, surgiram a jurisprudência dos interesses, cujo expoente maior foi Philipp Heck, e o movimento do direito livre, expressão aparecida em uma conferência de Eugen Ehrlich em 1903. ${ }^{40}$

Ao examinar a livre investigação científica, Vicente Ráo manifestase no sentido de que esta "encontra sua melhor e mais exata qualificação dentro da teoria das lacunas do direito, pois sua finalidade consiste em suprir, mediante livre apuração de novas regras, as omissões, os vazios, que por outro modo se não possam preencher, das normas jurídicas existentes". ${ }^{41}$

De fato, parece que o alvo principal da crítica de Gény era a idéia de

AUSTIN, John, The Province of Jurisprudence Determined, [s/d], p. 2. 
esgotamento do direito na legislação, ${ }^{42}$ tão ao gosto dos juristas franceses do Século XIX, à qual se ligava também uma crítica à teoria hermenêutica que considerava que a interpretação/aplicação do direito se resumia à subsunção de um fato a uma lei preexistente. ${ }^{43}$ Essa crítica fica clara na lição de Gény:

As fontes formais do direito privado positivo, das quais procurei, no capítulo precedente, precisar o justo alcance e determinar o uso legítimo, dotam seguramente, no limite permitido em sua esfera de ação, da mais segura direção ao intérprete. Mas não pode ocultar-nos que, por penetrante e sutil que possa ser a interpretação dessas manifestações positivas do Direito, não se pode desconhecer sua natureza, e seria exceder seu próprio poder pretender que somente ela satisfizesse todas as aspirações da vida jurídica. Sobretudo - para não falar aqui mais do que da perfeita e mais fecunda, atualmente, das fontes mencionadas, a lei escrita - é claro que examinando-a tal como devemos fazê-lo, como um ato da inteligência e da vontade humana necessariamente limitada em seus propósitos, restrita também em seu alcance efetivo, pode-se assegurar que, por maior que seja a profundidade a que se chegue e por mais engenho que se ponha em solicitar a fórmula, não se poderá deduzir a plena totalidade das soluções que

42 Nas palavras de Maria Helena Diniz, “[...] diz François Gény, a

experiência demonstra que a lei escrita é incapaz de solucionar todos os problemas suscitados pelas relações sociais e até mesmo os casos que caem sob sua égide, isto porque a sua solução não depende somente da letra da lei mas também de ponderação dos fatos sociais concretos, por ser necessário investigar as realidades sociais concretas, para que a aplicação da leis produza os resultados perseguidos pelo legislador" (DINIZ, Maria Helena, Compêndio de Introdução à Ciência do Direito, 1993, p. 57).

43 Cf. BILLIER, Jean-Cassien; MARYIOLI, Aglaé, História da Filosofia do Direito, 2005, p. 270 e 271; CAMARGO, Maria Margarida Lacombe, Hermenêutica Jurídica e Argumentação: Uma Contribuição ao Estudo do Direito, 2001, p. 71; RECASÉNS SICHES, Luis, Panorama del Pensamiento Jurídico en el Siglo XX, 1963, p. 27. 
reclamam imperiosamente a infinita complexidade das relações sociais. ${ }^{44}$

O papel da livre investigação científica seria exatamente oferecer ao intérprete/aplicador do direito instrumental para superar as limitações imanentes ao direito positivo. ${ }^{45}$ Segundo Maria Margarida Lacombe Camargo "de acordo com Gény, uma vez não obtida a resposta para o problema no sistema, o aplicador da lei poderia, por meio da atividade científica, encontrar a solução jurídica fora do âmbito restrito da lei positiva".

Todavia, conforme adverte François Gény, a idéia de superação da vinculação absoluta entre o juiz e o direito positivo, não significa o império do subjetivismo judicante, com a prevalência do entendimento pessoal do magistrado. É seguindo essa linha de raciocínio que afirma que poder o trabalho do juiz ser qualificado como "livre investigação científica; investigação livre, tendo em vista que se encontra subtraída à ação própria de uma autoridade positiva; investigação científica, ao próprio tempo, porque não pode encontrar bases sólidas além dos elementos objetivos que somente a ciência pode revelar". ${ }^{46}$

Assim, segundo Gény as fontes do direito dividem-se em quatro categorias distintas, enunciadas por Jean-Cassien Billier e Agalaé Maryioli:

[...] dados reais que constituem as realidades sociais, econômicas, físicas e também morais, sobre as quais se inscrevem as regras jurídicas; os dados históricos que constituem a tradição, a história institucional e tudo o que se liga à história particular de um país; os dados racionais que constituem tudo o que se refere à 'natureza das coisas ou do homem', a sua essência, apresentando as características da necessidade, da imutabilidade e da universalidade, em suma, que constituem 'o irredutível do direito natural'; os dados ideais que

44 GÉNY, François, Método de Interpretación y Fuentes en Derecho Privado Positivo, 1925, p. 520.

45 CAMARGO, Maria Margarida Lacombe, Hermenêutica Jurídica e Argumentação: Uma Contribuição ao Estudo do Direito, 2001, p. 71. 46 GÉNY, François, Método de Interpretación y Fuentes en Derecho Privado Positivo, 1925, p. 524. 
correspondem às aspirações mais profundas do homem. ${ }^{47}$

\subsection{A segunda fase do pensamento de Rudolf von Ihering}

Na Alemanha, a crítica ao formalismo da jurisprudência dos conceitos ganhou força na pena de Rudolf von Ihering que, como visto, inicialmente fora um de seus principais arautos.

Ihering pode ser considerado o precursor das concepções sociológicas do direito ${ }^{48}$ e da chamada jurisprudência dos interesses, ${ }^{49}$ na medida em que sustenta que "o direito é referido a um fim social, do qual recebe o seu conteúdo". 50

A teoria de Ihering encontra-se claramente exposta em sua obra $\mathrm{O}$ Fim no Direito, sendo que logo no capítulo primeiro do aludido trabalho ele assevera que:

Um ato de vontade sem causa final é um impossível tão absoluto como o movimento de uma pedra sem causa eficiente. Tal é a lei da causalidade: psicológica no primeiro caso, puramente mecânica no segundo. Para abreviar, chamarei desde logo a primeira lei de finalidade, para indicar assim, por seu mesmo nome, que a causa final é a única razão psicológica da vontade. Enquanto à lei de causalidade mecânica, o termo lei de causalidade bastará para designá-la daqui adiante. Esta lei, neste último sentido, pode explicar-se assim: nenhum acontecimento se produz no mundo físico sem um acontecimento anterior no qual encontra aquele sua causa. É a expressão habitual: não há efeito sem causa. A lei de finalidade diz: não há

47 BILlIER, Jean-Cassien; MARYIOLI, Aglaé, História da Filosofia do Direito, 2005, p. 272.

48 Cf. LATORRE, Angel, Introdução ao Direito, 2002, p. 185.

49 Cf. BILLIER, Jean-Cassien; MARYIOLI, Aglaé, História da Filosofia do Direito, 2005, p. 277.

50 KAUFMANN, Arthur, A problemática da filosofia do direito ao longo da história, 2002, p. 172. 


\section{ação sem causa. ${ }^{51}$}

Nesse contexto, o direito já não se pode separar dos fins sociais que se buscam alcançar, com o que não se pode enclausurar o jurídico nos conceitos aplicados de forma lógico-subsuntiva. Com Larenz podemos afirmar que para Ihering, o direito é "a norma coercitiva do Estado posta a serviço de um fim social". 52

Veja-se que Ihering não contesta a natureza do direito como um conjunto de normas alicerçadas no poder coativo do Estado, pelo contrário, resume o direito ao exercício da coação para a proteção dos fins sociais. ${ }^{53}$

Nesse cenário, o próprio Ihering questiona: “Qual é, pois, o fim do direito?" Ao que responde: "Vimos que o fim dos atos do ser animado reside na realização de suas condições de existência. Partindo dessa definição, podemos dizer que o direito representa a forma de garantia das condições da vida da sociedade, assegurada pelo poder coativo do Estado". ${ }^{4}$

Como bem percebido por Recaséns Siches, "segundo Ihering, o Direito não é a coisa mais alta que há no mundo, não é um fim em si mesmo. É somente um meio a serviço do fim. Este fim consiste na existência em sociedade". 55

\subsection{A jurisprudência dos interesses}

51 IHERING, Rudolf von. El Fin en el Derecho. Tradução Leonardo Rodriguez. Panplona: Analecta Editorial, 2005. p. 8

52 LARENZ, Karl, Metodologia da Ciência do Direito, 1997, p. 61.

53 Em textual: "Depois de muitas voltas chegamos ao final à forma superior de emprego da força para os fins humanos, a organização social da coação; em uma palavra: o Estado. Poderíamos facilitar a tarefa apoderando-nos imediatamente da idéia de a coação social realizada pelo Estado. Mas necessitávamos demonstrar que o direito não pode realizar sua missão enquanto não repouse sobre o Estado. Unicamente no Estado encontra o direito a condição de sua existência: a supremacia sobre a força. Somente no interior do Estado alcança o direito este fim. No exterior, no conflito entre os Estados, a força ante o mesmo se levanta como inimiga tão poderosa como antes de sua aparição histórica nas relações de indivíduo a indivíduo. Nesta região a questão do direito se converte de fato em uma questão de superioridade de forças" (IHERING, Rudolf von, El Fin en el Derecho, 2005, p. 194 e 195).

54 IHERING, Rudolf von, El Fin en el Derecho, 2005, p. 274.

55 RECASÉNS SICHES, Luis, Panorama del Pensamiento Jurídico en el Siglo XX, 1963, p. 271. 
Conforme referido pode-se considerar Rudolf von Ihering o precursor da jurisprudência dos interesses, todavia, o maior expoente dessa linha de pensamento foi Philipp Heck (1858-1943).

Heck era crítico da jurisprudência dos conceitos, a qual ele acusava de haver limitado o papel do juiz a uma "pura atividade gnosiológica", de modo que "a tarefa do juiz teria que se limitar a subsumir o caso ao conceito jurídico, negando-se-lhe toda atividade criadora do direito". ${ }^{56}$

Parte Philipp Heck do entendimento de que a lei criada pelo legislador não consegue englobar toda realidade social, de modo que caberia ao juiz, a partir de pontos de vistas teleológicos, criar a norma aplicável ao caso concreto. ${ }^{57}$ Conforme suas palavras, "o pensamento legislativo é necessariamente insuficiente, especialmente quando se trata da nova codificação de um grande âmbito de relações. Também a lei bem elaborada apresenta lacunas e contradições que exigem uma atividade complementadora". ${ }^{58}$

Seguindo essa linha de entendimentos, a interpretação jurídica deveria transcender o direito positivo, sendo integrada pela noção de interesse, corporificando a denominada jurisprudência dos interesses. Para Heck,

[...] a característica peculiar dessa tendência consiste em que ela utiliza como conceitos metódicos auxiliares o conceito de interesse e a série de noções que estão com conexão com ele: estimação de interesses, situação de interesses, conteúdo de interesses, etc. Utilizam-se estes conceitos na análise dos problemas normativos, e na estruturação da reflexão desses conceitos auxiliares é ademais imprescindível para uma mais profunda penetração. ${ }^{59}$

É assim que para Heck "toda decisão deve ser interpretada como uma delimitação de interesses contrapostos e como uma estimação desses 56 HECK, Philipp, El Problema de la Creación del Derecho, 1999, p. 21.

$57 \quad$ HECK, Philipp, El Problema de la Creación del Derecho, 1999, p. 52.

$58 \quad$ HECK, Philipp, El Problema de la Creación del Derecho, 1999, p. 52.

59 HECK, Philipp, El Problema de la Creación del Derecho, 1999, p. 61. 
interesses, conseguida mediante juízos e idéias de valor". ${ }^{60}$

Verifica-se, portanto, que com a jurisprudência dos interesses critica-se de modo implacável a idéia de que o direito limita-se à legislação positivada e sua aplicação silogística aos casos concretos, inserindo no processo hermenêutico a consideração teleológica dos interesses em jogo. ${ }^{61}$

Daí a ponderação de Larenz no sentido de que:

[...] Ao exortar o juiz a aplicar os juízos de valor contidos na lei com vista ao caso judicando, a jurisprudência dos interesses - embora não quebrasse verdadeiramente os limites do positivismo - teve uma atuação libertadora e fecunda sobre uma geração de juristas educada num pensamento formalista e no estrito positivismo legalista. E isto na medida tanto maior quanto aconselhou idêntico processo para o preenchimento das lacunas das leis, abrindo desta sorte ao juiz a possibilidade de desenvolver o direito não apenas na fidelidade à lei, mas de harmonia com as exigências da vida. [...]. ${ }^{62}$

Vê-se, portanto, que a jurisprudência dos interesses representa uma importante modificação na consideração do papel do intérprete, o qual passa a ter nos interesses outros horizontes além da letra do texto legal.

\subsection{O Movimento para o Direito Livre}

$60 \quad$ HECK, Philipp, El Problema de la Creación del Derecho, 1999, p. 65.

61 Cf. LATORRE, Angel, Introdução ao Direito, 2002, p. 187;

KAUFMANN, Arthur, A problemática da filosofia do direito ao longo da história, 2002, p. 173; CAMARGO, Maria Margarida Lacombe, Hermenêutica Jurídica e Argumentação: Uma Contribuição ao Estudo do Direito, 2001, p. 97; BILLIER, Jean-Cassien; MARYIOLI, Aglaé, História da Filosofia do Direito, 2005, p. 279; COING, Helmut, Elementos Fundamentais da Filosofia do Direito, 2002, p. 333; AFTALIÓN, Enrique R.; OLANO, Fernando García; VILANOVA, José, Introducción al Derecho, [196-], p. 814; RECASÉNS SICHES, Luis, Panorama del Pensamiento Jurídico en el Siglo XX, 1963, p. 275.

62 LARENZ, Karl, Metodologia da Ciência do Direito, 1997, p. 69. 
A expressão movimento para o direito livre foi cunhada por Eugen Ehrlich (1867-1922), embora para Larenz essa linha teórica tenha em Oskar Büllow seu precursor. ${ }^{63}$

Assim como os demais movimentos de crítica ao formalismo, o movimento para o direito livre volta-se contra a aplicação silogisticomecânica do direito. Ainda segundo Larenz,

[...] contra uma aplicação puramente esquemática do preceito da lei à situação da vida, acentua Ehrlich a importância de uma 'livre investigação do Direito'. Com o que não procura uma jurisprudência segundo a apreciação discricionária do juiz chamado a dar a decisão, mas uma jurisprudência que arranque a tradição jurídica e aspire ao 'Direito justo', no sentido de Stammler. ${ }^{64}$

Assim como na livre investigação científica de Gény, o movimento para o direito livre buscava solucionar o problema das lacunas jurídicas. Todavia, havia uma importante distinção entre o que seria uma lacuna para as duas escolas.

Com efeito, para os juristas do movimento para o direito livre haveria uma lacuna não só nos casos em que determinada situação fática houvesse se quedado fora do regramento legislativo, estando-se igualmente diante de uma lacuna nas situações em que a lei não dispusesse claramente qual seria a solução apropriada a um dado caso. ${ }^{65}$ Nesses casos, caberia ao julgador 63 LARENZ, Karl, Metodologia da Ciência do Direito, 1997, p. 78.

64 LARENZ, Karl, Metodologia da Ciência do Direito, 1997, p. 79.

65 Seguindo o magistério de Arthur Kaufmann: "Direito Livre quer dizer, no fundo: livre da lei. É certo que os representantes desse movimento sempre se opuseram à 'fábula-contra-legen', à acusação de que eles queriam permitir ao juiz ignorar a lei (vigente) e até decidir contra ela. De fato, os juristas do direito livre nunca ensinaram tal coisa. Eles apenas queriam indicar qual o procedimento a adotar o juiz, quando a lei apresentasse lacunas. Contudo, e é este o busílis da questão, segundo a concepção da doutrina no direito livre, a lei não tem lacunas apenas quando não contenha, de todo em todo, uma regulamentação aplicável ao caso, mas já aí onde não resolve o caso de forma expressa e inequívoca (hard case no sentido de H.L.A. Hart). E naturalmente que isto é o que acontece quase sempre, pelos menos em todos os casos discutíveis" (KAUFMANN, Arthur, A problemática da filosofia do direito ao longo da história, 2002, p. 175). Nesse 
buscar, fora do direito positivo, a solução do caso concreto.

3. O realismo jurídico, americano e escandinavo

O realismo jurídico surge nos Estados Unidos e em países escandinavos, tratando-se de uma corrente jurídica sociológica que se difere tanto do formalismo jurídico como das correntes jus naturalistas e axiológicas.

O realismo jurídico norte-americano tem em Oliver W. Holmes (1841-1935), Roscoe Pound (1870-1964), Benjamin Cardozo (1870-1938), Karl Llewellyn (1893-1962), Felix Cohen (1907-1953) e Jerome Frank (1889-1957) alguns de seus principais expoentes.

Já os principais defensores do realismo jurídico escandinavo são Axel Hägerström (1868-1939), Vilhelm Lundstedt (1882-1955), Karl Olivecrona (1897-1980) e Alf Ross (1899-1979), este último certamente o jurista realista cujas idéias foram mais difundidas no Brasil, principalmente em razão da tradução para o vernáculo de sua obra Direito e Justiça.

Assim como o positivismo jurídico, carece o realismo de uma uniformidade, de modo que é possível falar em várias correntes realistas. De toda forma, parece haver uma unidade na idéia de se buscar o direito não nas normas positivas, mas sim nas decisões das cortes, razão pela qual o realismo confere grande relevância à compreensão dos mecanismos que levam os tribunais a proferirem suas decisões. ${ }^{66}$

O realismo, portanto, não deixa de ser positivista, na medida em que pretende um conhecimento científico e não axiológico do direito. ${ }^{67}$ Todavia, instaura uma espécie de positivismo sociológico que o afasta das correntes formalistas legalistas como a escola da exegese, a jurisprudência dos conceitos e, posteriormente, a teoria pura do direito kelseniana.

O realismo americano tinha grande foco na indeterminação legal ${ }^{68} \mathrm{a}$

mesmo sentido: HESPANHA, António Manuel, Cultura Jurídica Européia: Síntese de um Milénio, 2003, p. 289; KLUG, Ulrich. Lógica Jurídica. Tradução J. C. Gardella. Bogotá: Themis, 2004. p. 11-12.

66 Nesse sentido, ver: GREEN, Michael Steven. Legal Realism as Theory of Law. William and Mary Law Review, Williamsburg, n. 46, abr. 2005, p. 1919-1920. 67 Cf. LEITER, Brian R. American Legal Realism. In: The Blackwell Guide to Philosophy of Law and Legal Theory. Oxford: Blackwell, 2003. Disponível em SSRN: http://ssrn.com/abstract=339562. Acesso em 21 de fevereiro de 2006. 68 Ver: LATORRE, Angel, Introdução ao Direito, 2002, p. 193. 
qual levaria a uma possibilidade de que decisões diversas se fundamentassem em um mesmo diploma normativo. Assim, segundo os realistas as decisões seriam influenciadas mais pelos fatos envolvidos na contenda do que propriamente nas leis evocadas pelas partes. ${ }^{69}$

Analisando-se o realismo escandinavo a partir das idéias de Alf Ross, percebe-se uma forte crítica ao jus naturalismo e a qualquer idéia metafísica de direito ${ }^{70}$ o que fica evidente na comparação que o jurista dinamarquês faz entre as regras jurídicas e as regras do jogo de xadrez:

Com base no que foi dito, formulo a seguinte hipótese: o conceito "direito vigente" (de Illinois, da Califórnia, da common law) pode ser em princípio explicado e definido da mesma maneira que o conceito "norma vigente de xadrez" (para dois jogadores quaisquer). Quer dizer, "direito vigente" significa o conjunto abstrato de idéias normativas que serve como um esquema interpretativo para os fenômenos do direito em ação, o que por sua vez significa que essas normas são efetivamente acatadas e que o são porque são experimentadas e sentidas como socialmente obrigatórias.

[...]

Vista sob essa luz, nossa conclusão preliminar, estou confiante, não será classificada de lugar comum. Essa análise de um modelo simples é

69 Cf. LEITER, Brian R, American Legal Realism. In: The Blackwell Guide to Philosophy of Law and Legal Theory. Oxford: Blackwell, 2003. Disponível em SSRN: http://ssrn.com/abstract=339562. Acesso em 21 de fevereiro de 2006; BILLIER, Jean-Cassien; MARYIOLI, Aglaé, História da Filosofia do Direito, 2005, p. 254-256.

$70 \quad$ Nas palavras de Maria Helena Diniz, "o realismo jurídico abrange correntes teóricas que se afastam de qualquer investigação jusfilosófica de ordem metafísica ou ideológica, negando todo fundamento absoluto à idéia do direito, considerando tão-somente a realidade jurídica, isto é, o direito efetivamente existente ou os fatos sociais e históricos que lhe deram origem. O realismo jurídico busca a realidade efetiva sobre a qual se apóia e dimana o direito, não a realidade sonhada ou ideal. Para os realistas, o direito real e efetivo é aquele que o tribunal declara ao tratar do caso concreto" (DINIZ, Maria Helena, Compêndio de Introdução à Ciência do Direito, 1993, p. 68). 
deliberadamente direcionada no sentido de suscitar dúvidas no que tange à necessidade de explicações metafísicas com respeito ao conceito do direito. A quem ocorreria buscar a validade das normas de xadrez numa validade a priori, numa idéia pura do xadrez concedida ao ser humano por Deus ou deduzida da razão humana eterna? Tal pensamento é ridículo porque não tomamos o xadrez tão a sério como o direito, e assim é porque há emoções mais fortes vinculadas aos conceitos jurídicos. Mas isto não constitui razão para crer que a análise lógica deva adotar uma postura fundamentalmente diferente em um e outro caso. ${ }^{71}$

Partindo dessa completa separação entre direito e moral e do abandono da idéia de que existe uma noção metafísica de Direito, Ross defende que qualquer ordem jurídica coativa pode ser denominada direito, inclusive o ordenamento jurídico do nacional socialismo. Assim, a classificação de um conjunto de regras como direito nada teria a ver com a concordância ou discordância com as suas prescrições. ${ }^{72}$

71 ROSS, Alf. Direito e Justiça. Tradução Edson Bini. Bauru: EDIPRO, 2000. p. 41 e 42.

72 ROSS, Alf. Direito e Justiça, 2000, p. 55 e 56. Em outra obra, afirma Ross: "De acordo com a visão corrente, o objeto da ciência jurídica é o chamado direito positivo, a lei em vigor. O que isso quer dizer? Como uma explicação preliminar talvez se possa dizer que por isso se queira significar um sistema de leis gerais, determinadas por algumas características externas relacionadas à sua gênese, as quais constituem as leis de uma certa comunidade, conforme são aplicadas ou deveriam ser aplicadas pelas cortes de um país. Que a lei seja chamada 'positiva' ou 'em vigor' significa em primeiro lugar que essa lei é historicamente estabelecida e passou a existir como um fato que prevalece e que, independentemente da justiça das regras de acordo com normas ideais, válidas por si mesmas, devem ser aceitas. Entendida desse modo, a positividade da lei significa o mesmo que seu caráter de determinação autoritária. Sua validade não decorre de princípios racionais, mas de autoridade historicamente conferida. Em segundo lugar isso significa que o ordenamento não é apenas um sistema de leis válidas, mas leis que realmente, em conjunto, são observadas. Compreendida dessa forma a positividade da lei significa o mesmo que sua efetividade. Em ambos os casos encontra-se expresso que a lei é um fato, o qual encontra-se sujeito a um 
Todavia, para Alf Ross não se encontra o direito no texto das leis, mas nas decisões das cortes. Daí porque defende ele que

[...] o fator decisivo que determina que a proibição é direito vigente é tão-somente o fato de ser efetivamente aplicada pelos tribunais nos casos em que transgressões à lei são descobertas e julgadas. Não faz diferença se as pessoas acatam a proibição ou com freqüência a ignoram. Esta indiferença se traduz no aparente paradoxo segundo o qual quanto mais é uma regra acatada na vida jurídica extrajudicial, mais difícil é verificar se essa regra detém vigência, já que os tribunais têm uma oportunidade muito menor de manifestar sua reação. ${ }^{73}$

Da mesma forma que seus colegas norte-americanos, Alf Ross sustenta a indeterminação normativa, a qual, em sua percepção, teria como conseqüência a impossibilidade de se extrair qualquer resultado correto ao cabo do processo hermenêutico. ${ }^{74}$

Assim, a interpretação seria menos um método para compreensão dos textos legais e mais um instrumento para análise da produção da decisão de um tribunal. Nas palavras de Alf Ross,

[...] temos que analisar, portanto, a prática dos tribunais e nos empenharmos em descobrir os princípios ou regras que realmente os norteiam no trânsito da regra geral à decisão particular. Denomina-se essa atividade método jurídico, ou, no caso da aplicação do direito formulado (direito

exame empírico e não racional" (ROSS, Alf. Towards a Realistic Jurisprudence. Tradução Annie I. Fausboll. [s/1]: Scientia Verlad Aalen, 1989. p. 19). Para um comentário abalisado da comparação feita por Ross entre as normas jurídicas e as regras do jogo de xadrez, ver: HART, H. L. A. Scandinavian Realism. In: Essays in Jurisprudence and Philosophy. New York: Oxford University Press, 2001. p. 164165).

73 ROSS, Alf. Direito e Justiça, 2000, p. 59.

74 ROSS, Alf. Direito e Justiça, 2000, p. 167. 
legislado em lato sentido), interpretação. ${ }^{75}$

\section{O retorno do formalismo no século XX}

\subsection{O positivismo jurídico de Hans Kelsen}

Como vimos anteriormente, durante o século XIX e início do século XX desenvolveram-se diversos movimentos jurídicos que buscavam a superação das escolas formalistas, buscando-se integrar ao direito dados factuais ocorridos no meio social.

Foi exatamente contra essa "contaminação" do jurídico por outras ciências como a sociologia, a política e a psicologia que se insurgiu o jusfilósofo austríaco Hans Kelsen (1881-1973).

É impossível resumir em poucos parágrafos uma obra que, como apontado por Tércio Sampaio Ferraz Júnior, entre traduções e reimpressões alcança mais de 620 títulos e cujos textos elaborados sobre a mesma supera o número $1.200 .^{76}$

Dessa forma, trataremos brevemente aqui apenas de dois aspectos da teoria pura do direito: a relação entre direito e moral e a questão da interpretação jurídica.

Logo na introdução de sua teoria pura do direito Kelsen deixa claro seu propósito de estabelecer uma teoria baseada nas normas jurídicas, excluindo tudo que em seu sentir thes fosse alheio, elevando a ciência jurídica a um patamar científico nunca dantes alcançado. ${ }^{77}$ Vejam-se os primeiros parágrafos da referida obra:

A Teoria Pura do Direito é uma teoria do Direito

75 ROSS, Alf. Direito e Justiça, 2000, p. 136.

76 FERRAZ JÚNIOR, Tércio Sampaio. Por que ler Kelsen, hoje. In:

COELHO, Fábio Ulhoa. Para Entender Kelsen. 4. ed. São Paulo: Saraiva, 2001. p. XIII.

77 Assim leciona Karl Larenz, para quem "foi Hans Kelsen quem, com admirável energia e improbo rigor de pensamento, se desempenhou de semelhante missão. A sua 'teoria pura do Direito' constitui a mais grandiosa tentativa de fundamentação da ciência do Direito como ciência - mantendo-se embora sob o império do conceito positivista desta última e sofrendo das respectivas limitações - que o nosso século veio até hoje a conhecer" (LARENZ, Karl, Metodologia da Ciência do Direito, 1997, p. 92). 
positivo - do direito positivo em geral, não de uma ordem jurídica especial. É teoria geral do Direito, não interpretação de particulares normas jurídicas, nacionais ou internacionais. Contudo, fornece uma teoria da interpretação.

Como teoria, quer única e exclusivamente conhecer o seu próprio objeto. Procura responder a esta questão: o que é e como é o Direito? Mas já lhe não importa a questão de saber como deve ser o Direito, ou como deve ele ser feito. É ciência jurídica e não política do Direito.

Quando a si própria se designa como "pura" teoria do Direito, isto significa que ela se propõe garantir um conhecimento apenas dirigido ao Direito e excluir deste conhecimento tudo quanto se não possa, rigorosamente, determinar como Direito. Quer isto dizer que ela pretende libertar a ciência jurídica de todos os elementos que lhe são estranhos. Esse é o seu princípio metodológico fundamental. ${ }^{78}$

Diferentemente do que muitas vezes se afirma na doutrina, a teoria pura do direito não nega a grande importância da ética, da moral e da justiça para o direito, mas sim a inexistência de uma moral ${ }^{79}$ ou de uma justiça ${ }^{80}$ absolutas, que devam ser acolhidas pelas normas jurídicas. Separa-se, aqui, o campo da ciência jurídica, preocupada com as normas positivadas, e da filosofia jurídica, voltada para análise dos fins que deveriam ser perseguidos pelo ordenamento e das normas em vigor como aptas para realizá-los. ${ }^{81}$ 78 KELSEN, Hans. Teoria Pura do Direito. 6. ed. Tradução João Baptista Machado. Coimbra: Armenio Amado, 1984. p. 17.

79 Cf. KELSEN, Hans, Teoria Pura do Direito, 1984, p. 100-102.

80 Cf. KELSEN, Hans. O Problema da Justiça. Tradução João Baptista Machado. São Paulo: Martins Fontes, 1998. p. 65.

81 António Manuel Hespanha ressaltou os méritos da teoria pura do direito, ao afirmar que: "A teoria pura do direito teve a virtude de, num período de intenso debate político-ideológico (os anos '30 a '50 do século XX), ter sublinhado a autonomia do saber jurídico e a sua relativa indisponibilidade em relação aos projetos de poder. Nesta medida, culminou as preocupações da pandectística em estabelecer que nem tudo quanto é querido pelo poder, útil ao povo ou a uma classe, ou funcional em relação a um objetivo social, é automaticamente aceite como justo (i.e., conforme ao direito). A juridicidade parece decorrer de valores internos ao discurso do direito, valores que a vontade política ou a utilidade social 
Seguindo essa linha de raciocínio, a teoria da interpretação jurídica apresentada por Kelsen mostra-se igualmente avalorativa.

Parte Kelsen de sua estrutura piramidal do ordenamento jurídico para definir a interpretação como "uma operação mental que acompanha o processo da aplicação do Direito no seu progredir de um escalão superior para um escalão inferior". 82

Assim, o legislador deve interpretar a Constituição para poder elaborar as leis infraconstitucionais, da mesma forma que o juiz e o administrador devem interpretar as normas do ordenamento jurídico para emitirem suas sentenças e atos administrativos, no contínuo movimento de positivação/concretização das normas jurídicas em atos de aplicação.

Nesse contexto, separa Kelsen a interpretação realizada por um órgão de aplicação do direito (ou seja, a interpretação apta à criação de uma norma individual e concreta) e a interpretação realizada por quem não é aplicador da regra interpretada (por exemplo, interpretação realizada pelas pessoas de direito privado que devem observar o direito e aquela oferecida pela ciência jurídica).

Aspecto importantíssimo da teoria da interpretação kelseniana é a indeterminação dos textos normativos da qual decorre a idéia de que estas são molduras, dentro das quais podem ser identificadas mais de uma norma jurídica. Em suas palavras:

Se por "interpretação" se entende a fixação por via cognoscitiva do sentido do objeto a interpretar, o resultado de uma interpretação jurídica somente

não podem substituir.

Neste sentido, embora se possa acusar a teoria pura do direito de aceitar como direito tudo o que provém da vontade do Estado, o certo é que o seu sentido mais profundo é o de constituir um manifesto contra os totalitarismos políticos do seu tempo, que, num sentido ou noutro, procuravam funcionalizar o direito em relação às conveniências do poder, legitimando-o a partir de considerações políticas, como o domínio de classe (estalinismo) ou as necessidades vitais de uma raça (nacionalsocialismo). Há que pense que este manifesto é ainda útil contra outro tipo de funcionalizações do direito, nomeadamente, a tendência para justificar como justas as medidas - formal ou informalmente corretas - de um poder legitimado pelo voto, ou as medidas dirigidas à consecução de finalidades de desenvolvimento social ou econômico" (HESPANHA, António Manuel, Cultura Jurídica Européia: Síntese de um Milénio, 2003, p. 310).

82 KELSEN, Hans, Teoria Pura do Direito, 1984, p. 463. 
pode ser a fixação da moldura que representa o Direito a interpretar e, conseqüentemente, o conhecimento das várias possibilidades que dentro desta moldura existem. Sendo assim, a interpretação de uma lei não deve necessariamente conduzir a uma única solução como sendo a única correta, mas possivelmente a várias soluções que - na medida em que apenas sejam aferidas pela lei a aplicar - têm igual valor, se bem que apenas uma delas se torne Direito positivo no ato do órgão aplicador do Direito - no ato do Tribunal, especialmente. Dizer que uma sentença judicial é fundada na lei não significa, na verdade, senão que ela se contém dentro da moldura ou quadro que a lei representa - não significa que ela é a norma individual, mas apenas que é uma das normas individuais que podem ser produzidas dentro da moldura da norma geral. ${ }^{83}$

Ao afirmar que o texto legal é apenas uma moldura dentro da qual se encontram diversas normas jurídicas passíveis de serem criadas pelo aplicador do direito, Kelsen rejeita a possibilidade de que se desenvolva qualquer método jurídico capaz de definir qual seria a norma jurídica correta extraível do texto. ${ }^{84}$

Seguindo essa linha de raciocínio, sustenta Hans Kelsen que a escolha de uma entre as diversas normas jurídicas contidas na moldura do texto legal sequer seria uma atividade jurídica, mas sim uma atividade de política do direito. ${ }^{85}$

83 KELSEN, Hans, Teoria Pura do Direito, 1984, p. 467.

84 KELSEN, Hans, Teoria Pura do Direito, 1984, p. 468.

85 Em suas palavras: "A questão de saber qual é, de entre as possibilidades que se apresentam nos quadros do Direito a aplicar, a 'correta', não é sequer segundo o próprio pressuposto de que se parte - uma questão de conhecimento dirigido ao Direito positivo, não é um problema de teoria do Direito, mas um problema de política do Direito. A tarefa que consiste em obter, a partir da lei, a única sentença justa (certa) ou o único ato administrativo correto é, no essencial, idêntica à tarefa de quem se proponha, nos quadros da Constituição, criar as únicas leis justas (certas). Assim como da Constituição, através de interpretação, não 
Portanto, não sendo a eleição de uma entre as normas constantes no texto legal uma atividade jurídica, pode a mesma muito bem ser guiada por critérios metajurídicos, como a moral e a justiça.

Em assim sendo, jamais seria possível determinar se a norma eleita seria efetivamente a "correta", já que pautada tal escolha por elementos estranhos ao direito. Como aduz Kelsen, "do ponto de vista do Direito positivo, nada se pode dizer sobe a sua validade e verificabilidade. Deste ponto de vista, todas as determinações desta espécie apenas podem ser caracterizadas negativamente: são determinações que não resultam do próprio Direito positivo". ${ }^{86}$

\subsection{O positivismo jurídico de Herbert L. A. Hart}

O jusfilósofo inglês Herbert L. A. Hart (1907-1992) foi o outro grande nome do positivismo jurídico no século XX.

Assim como Kelsen, Hart reconhece a indeterminação dos textos legais, desenvolvendo a teoria da textura aberta da linguagem.

Segundo o professor inglês, "qualquer instrumento, precedente ou legislação, seja escolhido para a comunicação de padrões de comportamento, estes, a despeito do quão bem funcionem em um grande número de casos ordinários, em algum ponto em que sua aplicação esteja em questão, irão provar-se indeterminados; eles terão o que foi denominada uma textura aberta. Até aqui nós apresentamos tal fato, no caso da legislação, como uma característica geral da linguagem humana; incerteza nos limites é o preço a ser pago pelo uso de termos gerais classificatórios em qualquer forma de comunicação relativa a temas factuais". ${ }^{87}$

Partindo da textura aberta das normas jurídicas, critica Hart o formalismo conceitualista, que pretendia enclausurar a realidade em conceitos. $^{88}$

podemos extrair as únicas leis corretas, tão-pouco podemos, a partir da lei, por interpretação, obter as únicas sentenças corretas" (KELSEN, Hans, Teoria Pura do Direito, 1984, p. 469).

86 KELSEN, Hans, Teoria Pura do Direito, 1984, p. 470.

87 HART, H. L. A. The Concept of Law. 2nd. ed. New York: Oxford University Press, 1997. p. 128. Sobre a textura aberta da linguagem, ver: STRUCHINER, Noel. Direito e Linguagem: Uma Análise da Textura Aberta da Linguagem e sua Aplicação ao Direito. Rio de Janeiro: Renovar, 2002.

HART, H. L. A, The Concept of Law, 1997, p. 129. 
A indeterminação legal confere às cortes e autoridades encarregadas de aplicar a norma jurídica uma certa margem para "ponderar, diante das circunstâncias, entre interesses conflitantes que podem variar em peso de caso para caso". 89

Dessa forma, a textura aberta das normas jurídicas deixa ao juiz um poder criativo, a ser exercido mediante interpretação/aplicação de precedentes ou estatutos aos casos concretos. De outro lado, cabem à cortes dar a última palavra sobre o que é o direito, ${ }^{90}$ no exercício de sua discricionariedade. ${ }^{91}$

A textura aberta das normas de Hart difere, porém, da idéia do texto legal como moldura trazida por Kelsen. De fato, para Hart a abertura das normas pode levar a uma situação de ausência de qualquer norma jurídica, verdadeira lacuna a ser superada pela discricionariedade do juiz. ${ }^{92}$ Já o textomoldura de Kelsen significaria a existência de várias normas que poderiam ser potencialmente extraídas de um dado texto legal e não a existência de uma lacuna.

Para Hart, tal competência discricionária atribuída ao juiz não é ilimitada, não sendo equivalente à competência atribuída aos órgãos legislativos.

Com efeito, Hart sustenta que o exercício desta competência discricionária se dá dentro dos limites do próprio ordenamento jurídico, de onde o julgador extrairá os parâmetros para sua decisão. Exatamente por tal motivo, pelo fato de que o próprio ordenamento orienta o juiz na apreciação dos casos concretos é que para Hart uma decisão jurídica racional não depende de apelação para critérios morais de como a lei deveria ser. ${ }^{93}$

\section{A hermenêutica filosófica de Hans-Georg Gadamer}

O filósofo alemão Hans-Georg Gadamer (1900-2002), mesmo não sendo filósofo do direito e, portanto, não tendo posto a hermenêutica jurídica entre suas principais preocupações, desenvolveu, a partir da virada ontológica conduzida por seu mestre Martin Heidegger, uma hermenêutica

89 HART, H. L. A, The Concept of Law, 1997, p. 135.

90 HART, H. L. A, The Concept of Law, 1997, p. 145.

91 HART, H. L. A, The Concept of Law, 1997, p. 252.

92 HART, H. L. A, The Concept of Law, 1997, p. 272.

93 HART, H. L. A. Positivism and the Separation of Law and Morals. In: Essays in Jurisprudence and Philosophy. New York: Oxford University Press, 2001. p. 68-69. 
filosófica cujos fundamentos acabam por impor uma modificação no pensar a hermenêutica jurídica.

Entre as modificações trazidas pela hermenêutica filosófica de Hans-Georg Gadamer, destacamos três em especial: (a) a crítica quanto à crença na possibilidade de se alcançar a verdade nas ciências do espírito através da utilização de um método; (b) a revisão da idéia do distanciamento do intérprete em relação ao objeto interpretado, com o reconhecimento de que é no intérprete, com sua tradição e pré-conceitos, que se realiza o processo interpretativo; e (c) a inclusão da aplicação no âmbito do processo hermenêutico, a qual abala os alicerces do entendimento, difundido na seara jurídica, de que a aplicação seria um momento pós-interpretativo, em que o intérprete, estranho ao texto legal e aos fatos sob exame, aplica a estes o resultado da interpretação do texto, resolvendo uma controvérsia jurídica.

Uma breve reflexão acerca desses três pontos revela que os mesmos estão intimamente conectados. Com efeito, a partir do momento que intérprete e objeto implicam-se mutuamente, perde força a idéia de que intérprete e objeto relacionam-se por intermédio de um método que permite que aquele conheça e intérprete este, aplicando-o a outro objeto externo, ao final.

\subsection{Uma crítica ao método}

A obra principal de Hans-Georg Gadamer, Verdade e Método, editada pela primeira vez no ano de 1960 , tem como um de seus principais propósitos apresentar crítica à idéia de que se pode alcançar a verdade, no campo das ciências do espírito, mediante a mera aplicação de um método objetivo, nos moldes das ciências naturais.

Conforme afirma Gadamer logo na introdução de seu pensamento, "na origem, o fenômeno hermenêutico não é, de forma alguma, um problema de método". ${ }^{4}$

A crítica ao pensamento metodológico é tão presente em sua obra que alguns de seus críticos e revisores apontam que seu trabalho devia ser

94 GADAMER, Hans-Georg. Verdade e Método I: Traços de uma hermenêutica filosófica. 5. ed. Tradução Flávio Paulo Meurer. Petrópolis: Vozes, 2003. p. 29. 
intitulado Verdade ou Método,${ }^{95}$ ou ainda Verdade versus Método. ${ }^{96}$

A crítica de Gadamer, que pode certamente ser trazida para o campo da hermenêutica jurídica, deve, todavia, ser bem apreendida, de modo a se evitar uma má-compreensão de suas idéias.

De fato, os aportes gadamerianos não são contra a existência dos métodos. Como o próprio Gadamer afirma em entrevista concedida a Carsten Dutt, "é claro que há métodos, e certamente deve-se aprendê-los e aplicá-los". 97

O foco da crítica do professor de Heidelberg, portanto, não é a existência de métodos, mas sim a crença na objetivação da verdade por intermédio de seu uso, assim como a exterioridade metodológica do intérprete em relação ao objeto interpretado. Nas autorizadas palavras de Richard Palmer:

Assim como Heidegger, Gadamer é um crítico da moderna submissão ao pensamento tecnológico, o qual se encontra enraizado no subjetivismo (Subjektität) - ou seja, em tomar a consciência subjetiva do homem, e as certezas da razão na mesma baseadas, como o ponto máximo de referência para o conhecimento humano. Os filósofos pré-cartesianos, por exemplo, os gregos antigos, encaravam seu pensamento como uma parte do próprio ser; eles não tomavam a subjetividade como seu ponto de partida e então fundamentavam a objetividade de seu conhecimento sobre a mesma. Sua abordagem era mais dialética e tentava permitir-se ser guiada pela natureza do que estava sendo compreendido. Conhecimento não era algo que eles adquiriam como uma possessão, mas algo no qual eles participavam, permitindo que os mesmos fossem dirigidos e até mesmo possuídos por seu conhecimento. Nesse sentido

95 Cf. RICOEUR, Paul. Hermeneutics \& the Human Sciencies. Tradução de John B. Thompson. Cambridge: Cambridge University Press, 1998. p. 60.

96 Cf. GADAMER, Hans-Georg. Gadamer in Conversation. Tradução de Richard Palmer. New Haven/London: Yale University Press, 2001. p. 41.

97 Gadamer in Conversation, 2001, p. 41. 
os Gregos alcançaram uma abordagem da verdade que foi além das limitações do pensamento sujeitoobjeto moderno, enraizado em um conhecimento subjetivamente correto.

Dessa forma, a abordagem de Gadamer é mais próxima à dialética de Sócrates do que ao pensamento manipulativo e tecnológico moderno. A verdade não é alcançada metodicamente, mas dialeticamente; a abordagem dialética da verdade é vista como a antítese do método, como um meio de superar a tendência do método de pré-estruturar o modo de ver dos indivíduos. Falando mais exatamente, o método é incapaz de revelar novas verdades; ele apenas explicita o tipo de verdade que já se encontra explícita no próprio método.[...]. ${ }^{98}$

Richard Palmer explicita na passagem acima o foco central a crítica de Gadamer, a qual tem por fim uma mudança da função do método nas ciências humanas. Tal foco consiste na idéia de que a legitimação nas ciências do espírito se dá por intermédio da participação dialética do sujeito no processo hermenêutico, e não pela aplicação de qualquer método.

Ao responder questão acerca da crítica metodológica contida em sua obra, o próprio Gadamer responde que o que buscou "demonstrar é que o conceito de método não era caminho apropriado para se atingir legitimidade no campo das ciências humanas e sociais". 99 Conforme conclui "essa é a razão pela qual sugeri que o ideal de conhecimento objetivo, que domina nossos conceitos de conhecimento, ciência e verdade, precisa ser superado pelo ideal de compartilhar algo, de participação". ${ }^{100}$

A hermenêutica filosófica gadameriana é mesmo incompatível com a idéia de que se pode ter acesso à verdade através de um método aplicável pelo intérprete.

Com efeito, a teoria de Gadamer funda-se na concepção de que o homem tem acesso ao mundo pela linguagem, a qual deve ser interpretada (compreendida) pelo ser-aí (Dasein ${ }^{101}$ ), sendo assim pautada por sua tradição 98 PALMER, Richard. Hermeneutics. Evanston: Northwestern University Press, 1969. p. 164 e 165.

99 Gadamer in Conversation, 2001, p. 40.

100 Gadamer in Conversation, 2001, p. 40.

101 "Dasein: (al.: existência, ser-aí) Termo heideggeriano que significa realidade humana, ente humano, a quem somente o ser pode abrir-se. Mas como é ambíguo, correndo o risco de abrir uma brecha para o humanismo, Heidegger 
e suas pré-compreensões.

Ora, se a interpretação se desenvolve no âmbito do horizonte do intérprete, não se pode conceber que esta corresponda à aplicação de um método exterior ao mesmo. Como destaca Maria Margarida Lacombe Camargo, "Gadamer defende a idéia de que não é tarefa da hermenêutica descobrir métodos para uma correta interpretação, mas refletir sobre o acontecer da própria interpretação, que no âmbito das ciências do espírito corresponde mais especificamente à compreensão". ${ }^{102}$

Parece-nos evidente, à primeira vista, que os aportes teóricos de Hans-Georg Gadamer abalam a noção tradicional de método jurídico, ordinariamente entendido como instrumento à disposição do intérprete para se alcançar a verdade contida no texto legal.

Castanheira Neves dá-nos clara visão acerca do formalismo metodológico que por longo período dominou o cenário jurídico, o qual partia de uma deificação do ato legislativo que somente poderia ser alcançada mediante a neutralização do intérprete pela supervalorização do método jurídico. ${ }^{103}$

Esse pensamento metodológico formalista, nas palavras de François Gény, busca "dar alcance ao pensamento do legislador contido nos textos. Sempre que se compreenda e interprete bem a lei, subsumirá quantas soluções jurídicas sejam necessárias". ${ }^{104}$

Todavia, tendo por base as inflexões de Gadamer, tem-se que a relação sujeito-objeto não se dá por intermédio do método, mas sim dentro do próprio ser-aí, de modo que o objeto não é revelado pelo método, mas prefere utilizar a expressão ser-aí. Na linguagem corrente, Dasein quer dizer * existência humana. Enquanto os * entes são fechados em seu universo circundante, o homem é graças à linguagem, aí onde vem o ser. Assim, o Dasein é o ser do existente humano enquanto existência singular e concreta: 'A essência do seraí (Dasein) reside em sua existência (Existenz), isto é, no fato de ultrapassar, de transcender, de ser originariamente ser-no-mundo" (JAPIASSÚ, Hilton; MARCONDES, Danilo. Dicionário Básico de Filosofia. 3. ed. Rio de Janeiro: Jorge Zahar Editor, 1996. p. 63). Sobre o Dasein ver também: VATTIMO, Gianni. Introducción a Heidegger. Barcelona: Gedisa, 2002. p. 32-35.

102 CAMARGO, Maria Margarida Lacombe, Hermenêutica Jurídica e Argumentação: Uma Contribuição ao Estudo do Direito, 2001, p. 32.

103 Cf. NEVES, A. Castanheira. Metodologia Jurídica: Problemas Fundamentais. Coimbra: Coimbra Editora, 1993. p. 28.

104 GÉNY, François. Método de Interpretación y Fuentes em Derecho Privado Positivo. Madrid: Editorial Réus, 1925. p. 26. 
compreendido pelo ser.

Resta perguntar, então, qual o papel dos chamados métodos de interpretação jurídica?

Os ditos métodos jurídicos (elementos ou critérios de interpretação) nada mais são do que uma referência aos diversos aspectos envolvidos na compreensão dos textos legislativos e dos fatos jurídicos. ${ }^{105}$

Com efeito, tais métodos (gramatical, sistemático, teleológico, histórico, axiológico, etc.) lembram apenas os diversos aspectos envolvidos no fenômeno jurídico, não garantindo qualquer certeza ou correção ao resultado da interpretação em um caso particular. ${ }^{106}$

Seguindo as observações acima e tendo por fundamento as críticas de Gadamer à objetivação metodológica como instrumento à descoberta da verdade no âmbito das ciências humanas, é de se concluir que a crença nos métodos jurídicos como meios para o alcance da correção no campo da hermenêutica jurídica oferece algo que não pode alcançar.

Com efeito, é de se concordar com Eros Grau quando afirma que "a reflexão hermenêutica repudia a metodologia tradicional da interpretação e coloca sob acesas críticas a sistemática escolástica dos métodos, incapaz de responder à questão de se saber por que um determinado método deve ser, em determinado caso, escolhido". ${ }^{107}$

Pode-se concluir, portanto, que a correção das ciências humanas não pode ser objetivamente alcançada pela aplicação de métodos, o que implica em uma revisão da própria noção de hermenêutica jurídica, como passamos a examinar.

\subsection{A hermenêutica gadameriana e a hermenêutica jurídica}

\section{Cf. MÜLLER, Friedrich. Métodos de Trabalho do Direito}

Constitucional. 3. ed. Rio de Janeiro: Renovar, 2005. p. 27-30.

106 Sobre o tema, ver: STRECK, Lenio Luiz. O Efeito Vinculante das Súmulas e o Mito da Efetividade: Uma Crítica Hermenêutica. In: Crítica à Dogmática: Dos Bancos Acadêmicos à Prática dos Tribunais. Porto Alegre: Instituto de Hermenêutica Jurídica, 2005. p. 92; STRECK, Lenio Luiz. A hermenêutica filosófica e as possibilidades de superação do positivismo pelo (neo)constitucionalismo. In: STRECK, Lenio Luiz; ROCHA, Leonel Severo (Orgs.). Constituição, Sistemas Sociais e Hermenêutica. Porto Alegre: Livraria do Advogado, 2005. p. 167.

107 GRAU, Eros Roberto. Ensaio e Discurso sobre a Interpretação/ Aplicação do Direito. São Paulo: Malheiros, 2002. p. 90 e 91. 
É vetusto o entendimento de que a interpretação jurídica seria um método para a descoberta da norma contida no texto ou, melhor dizendo, para a descoberta do verdadeiro sentido do texto legal.

Não se reconhecia qualquer caráter criativo a tal atividade, pressupondo que, por via da interpretação, seria possível a descoberta do único sentido já contido no texto legal.

Exposição nessa linha encontra-se, por exemplo, em Carlos Maximiliano, para quem "interpretar é explicar, esclarecer; dar o significado de vocábulo, atitude ou gesto; reproduzir por outras palavras um pensamento exteriorizado; mostrar o sentido verdadeiro de uma expressão; extrair, de frase, sentença ou norma, tudo o que na mesma se contém". ${ }^{108}$

Embora tal concepção acerca da interpretação tenha sido abandonada há muito, até mesmo por autores positivistas como Kelsen e Hart, a mesma ainda é sustentada aqui e alhures.

Tal doutrina encontra-se, portanto, em cheque, podendo tal fato ser explicado a partir da hermenêutica filosófica gadameriana.

Com efeito, um primeiro fundamento para a crise do conceito tradicional de interpretação jurídica o temos nas próprias críticas formuladas à objetividade metodológica nas ciências humanas.

Partindo-se da premissa de que não há um método que possa ser

108 MAXIMILIANO, Carlos. Hermenêutica e Aplicação do Direito. 18. ed. Rio de Janeiro: Forense, 1999. p. 9. A idéia de que a interpretação consiste em uma atividade voltada para a descoberta do "verdadeiro" sentido de um texto legal encontra-se presente nos trabalhos de estudiosos da teoria geral do direito e nos compêndios gerais dos diversos "ramos" jurídicos, como em: MÁYNEZ, Eduardo García, Introducción al Estudio del Derecho, 2002, p. 327; COING, Helmut, Elementos Fundamentais da Filosofia do Direito, 2002, p. 326; GUSMÃO, Paulo Dourado de. Introdução ao Estudo do Direito. 26. ed. Rio de Janeiro: Forense, 1999. p. 219; DINIZ, Maria Helena, Compêndio de Introdução à Ciência do Direito, 1993, p. 381; LOPES, Miguel Maria de Serpa. Curso de Direito Civil. 7. ed. Rio de Janeiro: Freitas Bastos, 1989. v. I. p. 114; RODRIGUES, Silvio. Direito Civil. 20. ed. São Paulo: Saraiva, 1989. v. I. p. 24; ESPÍNOLA, Eduardo. Sistema de Direito Civil. Rio de Janeiro: Editora Rio, 1977. p. 157; BEVILAQUA, Clovis. Teoria Geral do Direito Civil. Rio de Janeiro: Editora Rio, 1975. p. 45; JESUS, Damásio E. de. Direito Penal. 19. ed. São Paulo: Saraiva, 1995. v. I. p. 27; MIRABETE, Julio Fabrini. Manual de Direito Penal. São Paulo: Atlas, 1998. v. I. p. 51; DANTAS, Ivo. Princípios Constitucionais e Interpretação Constitucional. Rio de Janeiro: Lúmen Júris, 1995. p. 83. 
aplicado pelo sujeito a um objeto com vistas a se alcançar a verdade nas ciências humanas, a idéias de que a interpretação de um texto presta-se ao alcance de tal verdade mostra-se inviável.

Além da crítica à objetividade metodológica, também o reconhecimento de que toda tarefa hermenêutica encontra-se influenciada pela pré-compreensão do intérprete também abala os alicerces de uma concepção estéril da interpretação jurídica.

A questão dos pré-conceitos e de sua influência no processo hermenêutico encontra-se vinculada à idéia de tradição ou, em outras palavras, à inserção do sujeito em uma determinada tradição, a qual pauta e condiciona sua forma de compreender o mundo. ${ }^{109}$ Como destaca Gadamer:

[...] encontramo-nos sempre inseridos na tradição, e essa não é uma inserção objetiva, como se o que a tradição nos diz pudesse ser pensado como estranho ou alheio; trata-se sempre de algo próprio, modelo e intimidação, um reconhecer a si mesmos no qual nosso juízo histórico posterior não verá tanto um conhecimento, mas uma transformação espontânea e imperceptível da tradição. ${ }^{110}$

109 Para Maria Margarida Lacombe Camargo, "Gadamer legitima a précompreensão na tradição como processo histórico que o intérprete experimenta. A autoridade da tradição, no entanto, não tira a liberdade do intérprete, uma vez que passe a ser racionalmente conhecida, pois, a partir do momento que formamos uma consciência metódica da compreensão, somos capazes de controlála. Mas a compreensão não consiste em uma busca do passado feita por uma razão independente, como procedia o romantismo histórico, considera Gadamer. Consiste, outrossim, na determinação universal do estar aí, isto é, na futuridade do estar aí, feita por uma razão comprometida historicamente. O estar ai faz parte de um processo histórico enquanto experiência humana da qual participamos" (Hermenêutica Jurídica e Argumentação: Uma Contribuição ao Estudo do Direito, 2001, p. 57 e 58).

110 Verdade e Método I: Traços de uma hermenêutica filosófica, 2003, p. 374. Vale a pena mencionar aqui as palavras de David E. Linge sobre a importância da pré-compreensão na hermenêutica jurídica gadameriana: "Não é de surpreender que a noção de pré-conceitos de Gadamer seja um dos aspectos mais controvertidos de sua filosofia. Mais do que qualquer outro elemento de seu pensamento, ela indica sua determinação em reconhecer as insuperáveis finitude e historicidade do compreender, assim como em exibir o papel positivo que 
Segundo Gadamer, pré-conceito "quer dizer um juízo que se forma antes do exame definitivo de todos os momentos segundo a coisa em questão". 111

Ora, o experimentar o mundo dos seres humanos lhes proporciona um conjunto de juízos prévios que condicionam o seu agir hermenêutico em relação a tudo quanto os cerca, de modo que nenhuma experiência sua será plenamente objetiva. ${ }^{112}$

os mesmos têm em cada transmissão humana de significado. Para Gadamer, o passado tem um poder pervasivo sobre o fenômeno da compreensão, e tal poder foi completamente ignorado pelos filósofos que dominaram a cena antes de Heidegger. O papel do passado não pode ser restringido meramente ao fornecimento de textos e eventos para a composição de 'objetos' da interpretação. Como os pré-conceitos e a tradição, o passado também define o ponto que o próprio intérprete ocupa quando compreende" (LINGE, David E. [Introduction to Gadamer's Philosofical Hermeneutics]. In: GADAMER, Hans-Georg. Philosofical Hermeneutics. Tradução David E. Linge. Berkeley/Los Angeles/London: University of California Press, 1997. p. xv).

111 Verdade e Método I: Traços de uma hermenêutica filosófica, 2003, p. 360. 112 Essa questão foi muito bem analisada e exposta por Eduardo C. B. Bittar, na passagem a seguir transcrita: "O ser-no-mundo carrega esta experiência de estar-aí (Dasein) da qual não pode se desvincular; não posso modificar minha compreensão-de-mundo, pois ela é já determinada pela minha história-de-mundo, da qual não posso me alhear. As condições existenciais (ek-sistere), estar-aí) em que sou posto determinam também as condições com as quais interpreto e comvivo com o mundo. A existência ou não dos "pré-conceitos" na determinação de todo sentido apreendido do mundo não depende da vontade humana. Os "préconceitos" existem, no sentido deste estar-ai contra o qual não se pode lutar, e estão presentes na avaliação de cada peça de nossa interação com o mundo. A vontade pode dizer não e renunciar aos "pré-conceitos", mas esta é já uma postura claramente carregada de "pré-conceitos" e de tomadas de posição próprias de um sujeito histórico e gravado por uma experiência particular" (BITTAR, Eduardo C. B. Hans-Georg Gadamer: a experiência hermenêutica e a experiência jurídica. In: BOUCAULT, Carlos E. de Abreu; RODRIGUEZ, José Rodrigo. Hermenêutica Plural. São Paulo: Martins Fontes, 2002. p. 184 e 185). Segundo Konrad Hesse, "o intérprete não pode compreender o conteúdo da norma de um ponto situado fora da existência histórica, por se assim dizer, arquimédico, senão somente na situação histórica concreta, na qual ele se encontra, cuja maturidade enformou seus conteúdos de pensamento e determina seu saber e seu (pré)-juízo. Ele entende o conteúdo da norma de uma (pré)-compreensão, que 
Nessa linha de entendimento, na medida em que o ser-no-mundo não consegue interagir com a realidade ignorando seus pré-conceitos, dados pela tradição, caem por terra os ideais de objetivismo e neutralidade do intérprete, apregoados pelo formalismo jurídico.

É de se salientar, contudo, que a crítica ao objetivismo e o reconhecimento inevitável dos pré-conceitos no processo hermenêutico não transformam a interpretação em um fenômeno subjetivo. Nas palavras de Gadamer, "a compreensão deve ser pensada menos como uma ação da subjetividade e mais como um retroceder que penetra num acontecimento da tradição". ${ }^{113}$

De fato, em primeiro lugar deve-se ter em conta que os valores trazidos pela tradição não são experenciados com exclusividade pelo sujeitointérprete, mas por toda a coletividade, a qual compartilha determinada tradição.

Por outro lado, o fato de que somos guiados por pré-conceitos, dados pela tradição, não significa que nunca tenhamos qualquer controle sobre os mesmos ou, melhor dizendo, que não devamos questioná-los. Assim, como observa Gadamer:

[...] Aquele que quer compreender não pode se entregar de antemão ao arbítrio de suas próprias opiniões prévias, ignorando a opinião do texto da maneira mais obstinada e conseqüente possível - até que este acabe por não poder ser ignorado e derrube a suposta compreensão. Em princípio, quem quer compreender um texto deve estar disposto a deixar que este lhe diga alguma coisa. Por isso, uma consciência formada hermenêuticamente deve, desde o princípio, mostrar-se receptiva à alteridade do texto. Mas essa receptividade não

primeiramente lhe torna possível olhar a norma com certas esperanças, projetarse um sentido do todo e chegar a um anteprojeto que, então, em penetração mais profunda, carece de confirmação, correção e revisão até que, como resultado de aproximação permanente dos projetos revisados, cada vez, ao "objeto", determinese univocamente a unicidade do sentido" (HESSE, Konrad. Elementos de Direito Constitucional da República Federal da Alemanha. Tradução Luís Afonso Heck. Porto Alegre: Sergio Antonio Fabris, 1998. p. 61 e 62).

113 Verdade e Método I: Traços de uma hermenêutica filosófica, 2003, p. 385. 
pressupõe nem uma "neutralidade" com relação à coisa nem tampouco um anulamento de si mesma; implica antes uma destacada apropriação das opiniões prévias e preconceitos pessoais. O que importa é dar-se conta dos próprios pressupostos, a fim de que o próprio texto possa apresentar-se em sua alteridade, podendo assim confrontar sua verdade com as opiniões prévias pessoais. ${ }^{114}$

Ponto dos mais importantes presentes na passagem acima consiste, portanto, na necessidade de o intérprete não se fechar em suas opiniões prévias, abrindo-se para a alteridade do texto. ${ }^{115}$

114 Verdade e Método I: Traços de uma hermenêutica filosófica, 2003, p. 358. 115 Nas palavras de Lenio Streck: "Quando se ouve a alguém ou quando se empreende uma leitura, não é que tenhamos que esquecer todas as opiniões prévias sobre seu conteúdo, ou todas as opiniões próprias, diz o mestre. O que se exige é que simplesmente temos que estar abertos à opinião do outro ou do texto. Entretanto, essa abertura implica sempre que se coloque a opinião do outro em alguma classe de relação com o conjunto de opiniões próprias ou que um se coloque em certa relação com as do outro. Para Gadamer, aquele que pretende compreender não pode entregar-se desde o princípio à sorte de suas próprias opiniões prévias e ignorar a mais obstinada e conseqüentemente possível opinião do texto. Aquele que pretende compreender um texto tem que estar em princípio disposto a que o texto lhe diga algo" (STRECK, Lenio Luiz. Hermenêtica Jurídica (em) Crise. Porto Alegre: Livraria do Advogado, 2003. p. 201). A questão foi bem colocada por Kelly Susane Alflen da Silva, para quem "aquele que tem uma consciência formada hermenêuticamente tem que estar disposto a deixar que o texto lhe diga algo, a acolher a outreidade do texto. Acolher o dito pelo texto sem reparo dos prejuízos significa a perda do sentido da verdade e da verdade em geral, o que H.G. Gadamer chama de mendacidade. Na esfera hermenêutica, isso quer dizer a exclusão do outro da comunicação por causa da inconseqüência consigo mesmo e, dessa forma, a ação hermenêutica se torna baldia por falta de entendimento. Precisamente, por isso, o intérprete deve se livrar dos próprios prejuízos negativos, a fim de que o texto surja em sua outreidade. O contrário, o reforço dos prejuízos pela repetição obstinada, com excelência diz H.G. Gadamer, é próprio do dogmatismo, que é conhecido sob o pretexto de conhecimento sem pressupostos e de objetividade da ciência (jurídica), pela mera transferência do método de outras ciências como, por exemplo, a física, principalmente, quando a ciência é invocada como instância suprema de processos de decisão social. Nisso se encontra a tensão entre o objetivismo ingênuo e o desconhecimento da 
Nesse ponto, parte Gadamer da dialética platônica para sustentar a primazia hermenêutica da pergunta. Citando uma vez mais suas lições:

Nós perguntamos pela estrutura lógica da abertura que caracteriza a consciência hermenêutica, e é bom que não esqueçamos a importância do conceito de pergunta na análise da situação hermenêutica. É claro que toda experiência pressupõe a estrutura da pergunta. Não se fazem experiências sem a atividade do perguntar. O conhecimento de que algo é assim, e não como acreditávamos inicialmente, pressupõe evidentemente a passagem pela pergunta para saber se a coisa é assim ou assado. Do ponto de vista lógico, a abertura que está na essência da experiência é essa abertura do "assim ou assado". Ela tem a estrutura da pergunta. E assim como a negatividade dialética da experiência consumada, onde temos plena consciência de nossa finitude e limitação, também a forma lógica da pergunta e a negatividade que lhe é inerente encontram sua consumação numa negatividade radical: no saber que não sabe. É a famosa docta ignorantia socrática que abre a verdadeira superioridade da pergunta na negatividade extrema da aporia. É preciso então que nos aprofundemos na essência da pergunta, se quisermos esclarecer em que consiste o modo peculiar de realização da experiência

verdade, i.e., dos interesses agregados ao conhecimento. Particularmente, por isso, considera-se a tarefa hermenêutica suprema; por seu intermédio é possível compreender, explicar e, por conseguinte, dissolver hábitos e prejuízos sociais arraigados imperantes, sobretudo a influência desses na atuação dos profissionais da área jurídica, embora seja uma tarefa difícil, porque colocar em dúvida o que é dogma provoca sempre a resistência de todas as evidências práticas" (SILVA, Kelly Susane Alflen da. Hermenêutica Jurídica e Concretização Judicial. Porto Alegre: Sergio Antonio Fabris Editor, 2000. p. 269). Ver, também: CUNHA, José Ricardo. Fundamentos Axiológicos da Hermenêutica Jurídica. In: BOUCAULT, Carlos E. de Abreu; RODRIGUEZ, José Rodrigo. Hermenêutica Plural. São Paulo: Martins Fontes, 2002. p. 321. 
hermenêutica. ${ }^{116}$

Dessa forma, o intérprete deve ter consciência de seus pré-conceitos (o que nem sempre é possível) para então iniciar uma relação dialética com o texto, abrindo-se para o mesmo mediante o procedimento de perguntas e respostas. ${ }^{117}$ Forma-se então o círculo da compreensão.

Com efeito, as opiniões prévias do intérprete permitem que ele interpele o texto, abrindo-se para o mesmo. Com a compreensão as opiniões prévias são substituídas por novas opiniões e assim por diante, em um constante "projetar de novo". ${ }^{118}$ Essa questão foi bem posta por Josef Bleicher, que ao analisar a hermenêutica filosófica gadameriana assim se manifesta:

116 Verdade e Método I: Traços de uma hermenêutica filosófica, 2003, p. 473. 117 Cf. GADAMER, Hans-Georg. La hermenêutica y la escuela de Dilthey. In: El Giro Hermenéutico. Tradução Arturo Parada. Madrid: Ediciones Cátedra, 1995. p. 146.

118 Segundo Gadamer: "[...] o processo descrito por Heidegger de que cada revisão do projeto prévio pode lançar um outro projeto de sentido; que projetos conflitantes podem posicionar-se lado a lado na elaboração, até que se confirme de modo mais unívoco a unicidade de sentido; que a interpretação começa com conceitos prévios substituídos depois por conceitos mais adequados. Em suma, esse constante projetar de novo é o que perfaz o movimento semântico de compreender e de interpretar. Quem procura compreender está sujeito a errar por causa das opiniões prévias, que não se confirmam nas coisas elas mesmas. Dessa forma, a constante tarefa do compreender consiste em elaborar projetos corretos, adequados às coisas, isto é, ousar hipóteses que só devem ser confirmadas 'nas coisas elas mesmas'. Aqui não há outra 'objetividade' além da elaboração da opinião prévia a ser confirmada. Faz sentido afirmar que o intérprete não vai diretamente ao 'texto', a partir da opinião prévia pronta e instalada nele. Ao contrário, põe à prova, de maneira expressa, a opinião prévia instalada nele a fim de comprovar sua legitimidade, o que significa, sua origem e sua validade" (GADAMER, Hans-Georg. Sobre o Círculo da Compreensão. In: Verdade e Método II. 2. ed. Petrópolis: Vozes, 2004. p. 75). Esse aspecto circular da compreensão é ressaltado por Gregorio Robles: “[...] a interpretação 'projeta', já que em todo momento começa com um 'projeto de compreensão' (pré-compreensão) que irá verificar-se e contrastar-se com a experiência. Este contraste mostrará a insuficiência do projeto emitido e a necessidade de substituí-lo por outro. Neste ir e vir da compreensão, para utilizar a expressão de Engisch, radica o chamado círculo hermenêutico" (ROBLES, Gregorio. Introducción a la Teoria del Derecho. 9. ed. Barcelona: Debate, 2003. p. 192). 
Aprincipal tarefa do intérpreteédescobrira pergunta a que o texto vem dar resposta; compreender um texto é compreender a pergunta. Simultaneamente, um texto só se torna um objeto da interpretação se confrontar o intérprete com uma pergunta. Nesta lógica de pergunta e resposta, um texto acaba por ser um acontecimento ao ser atualizado na compreensão, que representa uma possibilidade histórica. Conseqüentemente, o horizonte do sentido é limitado e a abertura, tanto do texto como do intérprete, constitui um elemento estrutural da fusão dos horizontes. Nesta concepção dialógica, os conceitos usados pelo Outro, seja um texto, seja um tu, ganham nova força, por se inserirem na compreensão do intérprete. Ao entendermos a pergunta colocada pelo texto, fizemos já perguntas a nós próprios e, por conseguinte, abrimo-nos a novas possibilidades de sentido. ${ }^{119}$

Ponto importante da hermenêutica filosófica de Gadamer reside no reconhecimento de que o homem somente recebe o mundo por intermédio da linguagem. ${ }^{120}$ Em suas palavras, a linguagem é "o centro do ser humano, quando considerada no âmbito que só ela consegue preencher: o âmbito da convivência humana, o âmbito do entendimento, do consenso crescente, tão indispensável à vida humana como o ar que respiramos". ${ }^{121}$

119 BLEICHER, Josef. Hermenêutica Contemporânea. Tradução Maria Georgina Segurado. Lisboa: Edições 70, [s/d]. p. 161.

120 Cf. PALMER, Richard, Hermeneutics, 1969, p. 205.

121 GADAMER, Hans-Georg. Homem e Linguagem. In: Verdade e Método II. 2. ed. Petrópolis: Vozes, 2004. p. 182. Ver, também: GADAMER, Hans-Georg. La Diversidade de las Lenguas y la Comprensión del Mundo. In: Arte y Verdad de la Palabra. Tradução José Francisco Zuñiga García. Barcelona: Paidós, 1998. p. 119. Sobre essa questão, nos diz Luiz Rohden que "com e pela linguagem, marca da finitude humana, a realidade constitui-se mediada lingüisticamente, e desse modo também a 'força de nossa reflexão é sempre uma força limitada pelo acontecer da lingüisticidade' que se compreende como 'condição e possibilidade de toda compreensão, a condição de possibilidade de que todo horizonte de sentido 
Ora, se experimentamos o mundo por intermédio da linguagem, devese concluir que o homem é um ser hermenêutico, ou seja, um ser que tem acesso ao mundo através da interpretação, de forma que é possível afirmar que estamos a todo tempo interpretando. ${ }^{122}$ É assim que, nas palavras de Gadamer, "todo compreender é interpretar e todo interpretar se desenvolve no medium de uma linguagem que pretende deixar falar o objeto, sendo, ao mesmo tempo, a própria linguagem do intérprete". ${ }^{123}$

$\mathrm{O}$ reconhecimento de que recebemos o mundo pela linguagem e que o tomamos por meio da interpretação torna inviável a idéia de uniformidade interpretativa, já que cada intérprete participa do processo hermenêutico munido de seus pré-conceitos, de modo que sua abertura ao texto se fará a partir de um determinado referencial de razões prévias, as quais pautarão às perguntas apresentadas e a formação do círculo da compreensão. Torna-se inevitável, então, reconhecer o caráter criativo do fenômeno hermenêutico. ${ }^{124}$

Em resumo, pode-se afirmar que a hermenêutica é o próprio modo de o homem se relacionar com o mundo, de se apropriar do mundo, e não um instrumento de que se pode valer para interpretar certos textos ou fatos, mediante a aplicação de um método. Nas palavras de Richard Palmer, na conclusão de sua análise sobre a teoria de Gadamer,

\section{[...]as chaves para compreensão não são}

seja determinado por sua vinculação ao acontecer da experiência humana finita'. Do ponto de vista da hermenêutica filosófica, a linguagem não é apenas condição de possibilidade, mas ela mesma é constituinte e constituidora do filosofar" (ROHDEN, Luiz. Hermenêutica Filosófica. São Leopoldo: Editora Unisinos, 2002. p. 227).

122 Como leciona Lenio Streck: "Dizendo de outro modo: estamos mergulhados em um mundo que somente aparece (como mundo) na e pela linguagem. Algo só é algo se podemos dizer que é algo. Esse poder-dizer é lingüisticamente mediato, porque nossa capacidade de agir e de dizer-o-mundo é limitado e capitaneado pela linguagem. Como diz Heidegger, todo o processo de compreensão do ser é limitado por uma história do ser que limita a compreensão. Gadamer, assim, eleva a linguagem ao mais alto patamar, em uma ontologia hermenêutica, entendendo, a partir disto, que é a linguagem que determina a compreensão e o próprio objeto hermenêutico. $\mathrm{O}$ existir já é um ato de compreender e um interpretar" (Hermenêutica Jurídica (em) Crise, 2003, p. 200). 123 Verdade e Método I: Traços de uma hermenêutica filosófica, 2003, p. 503. 124 Ver: STRECK, Lenio Luiz, Hermenêutica Jurídica (em) Crise, 2003, p. 203. 
manipulação e controle, mas participação e abertura, não é conhecimento, mas experiência, não é metodologia, mas dialética. Para ele [Gadamer], o propósito da hermenêutica não é estabelecer regras para uma compreensão objetivamente válida, mas conceber compreensão em si tão abrangente quanto possível. ${ }^{125}$

\subsection{Interpretação e aplicação}

Uma das conseqüências do objetivismo metodológico antes descrito é a separação dos momentos de interpretação e aplicação das normas jurídicas. Com efeito, sob os influxos dessa linha de pensamento tem-se uma separação bem definida entre o intérprete, o objeto da interpretação e a questão que se pretende solucionar.

Nesse cenário, o processo hermenêutico se daria em duas etapas distintas: em primeiro lugar, o intérprete desvelaria o sentido do texto legal para, então, aplicar a norma jurídica descoberta a uma determinada situação fática. É nesse sentido que se distinguem os momentos de interpretação e aplicação das normas jurídicas. ${ }^{126}$

Gadamer irá alocar todos os "momentos" da relação intérprete-

125 PALMER, Richard, Hermeneutics, 1969, p. 215.

126 Essa distinção entre interpretação e aplicação ainda encontra-se presente na doutrina. Nesse sentido, ver: MAXIMILIANO, Carlos, Hermenêutica e Aplicação do Direito, 1999, p. 6-8; FRANÇA, Limongi. Hermenêutica Jurídica. 7. ed. São Paulo: Saraiva, 1999. p. 35 e 36; PEREIRA, Caio Mário da Silva. Instituições de Direito Civil. 11. ed. Rio de Janeiro: Forense, 1989. v. I. p. 134; FERRARA, Francesco. Interpretação e Aplicação das Leis. 4. ed. Coimbra: Armênio Amado, 1987. p. 185; ASCENSÃO, José de Oliveira, Introdução à Ciência do Direito, 2005, p. 591; MÁYNEZ, Eduardo García. Introducción al Estudio del Derecho, 2002, p. 319; COING, Helmut, Elementos Fundamentais da Filosofia do Direito, 2002, p. 340 e 341; DINIZ, Maria Helena, Compêndio de Introdução à Ciência do Direito, 1993, p. 374; LOPES, Miguel Maria de Serpa, 1989, p. 111; RODRIGUES, Silvio, Direito Civil, 1989, p. 24; PECES-BARBA, Gregório; FERNÁNDEZ, Eusébio; ASÍS, Rafael. Curso de Teoría del Derecho. 2. ed. Madrid: Marcial Pons, 2000. p. 232; AMATUCCI, Andrea. La Interpretación de la Ley Tributaria. In: AMATUCCI, Andrea (Org.). Tratado de Derecho Tributario. Bogotá: Themis, 2001. p. 579-580; CARVALHO, Paulo de Barros. Curso de Direito Tributário. 15. ed. São Paulo: Saraiva, 2003. p. 88-90. 
objeto no âmbito da hermenêutica. Assim, a subtilitas intelligendi (o poder de compreender), a subtilitas explicandi (o poder de interpretar) e a subtilitas applicandi (o poder de aplicar) estão todas contidas no fenômeno hermenêutico. ${ }^{127}$

Nas palavras do mestre alemão, “'aplicar' não é ajustar uma generalidade já dada antecipadamente para desembaraçar em seguida os fios de uma situação particular. Diante de um texto, por exemplo, o intérprete não procura aplicar um critério geral a um caso particular: ele se interessa, ao contrário, pelo significado fundamentalmente original do escrito de que se ocupa". ${ }^{128}$

A inclusão da aplicação no processo hermenêutico é uma conseqüência lógica do abandono do objetivismo metodológico, já que a situação de fato que se põe ao intérprete será interpretada juntamente com o texto objeto da interpretação, implicando-se mutuamente e inserindo-se no âmbito da tradição (pré-compreensão) do intérprete.

Como salienta Josef Bleicher, "a 'aplicação', como articulação entre o passado e o presente, surge como terceiro momento da unidade da compreensão, da interpretação e da aplicação, que constituem o esforço hermenêutico: a compreensão adequada de um texto, que corresponde às suas necessidades e mensagem, muda com a situação concreta a partir da qual tem lugar; é já sempre uma aplicação". ${ }^{29}$

Esse aspecto da teoria de Hans-Georg Gadamer tem particular importância no âmbito jurídico, na medida em que se reconhecem as implicações entre norma e fato, não havendo que se falar em uma interpretação isolada dos textos normativos, desconsiderando-se os fatos envolvidos em dado caso concreto. ${ }^{130}$ Como fala-nos Lenio Streck, aprendemos com

127 Cf. GADAMER, Hans-Georg, Gadamer in Conversation, 2001, p. 37; GADAMER, Hans-Georg, Verdade e Método I: Traços de uma hermenêutica filosófica, 2003, p. 407.

128 GADAMER, Hans-Georg, O problema da consciência histórica, 1998, p. 57. Ver também: GADAMER, Hans-Georg. Hermenêutica clássica e hermenêutica filosófica. In: Verdade e Método II. 2. ed. Petrópolis: Vozes, 2004. p. 131.

129 BLEICHER, Josef, Hermenêutica Contemporânea, [s/d], p. 170.

130 Nas palavras de Eros Grau: "Interpretação e aplicação não se realizam autonomamente. $\mathrm{O}$ intérprete discerne o sentido do texto a partir e em virtude de um determinado caso dado; a interpretação do direito consiste em concretar a lei em cada caso, isto é, na sua aplicação. Assim, existe uma equação entre interpretação e aplicação: não estamos aqui diante de dois momentos distintos, 
Gadamer "que hermenêutica não é método, é filosofia". E prossegue: "Ora, se interpretar é aplicar, não há um pensamento teórico que 'flutua' sobre os objetos do mundo, apto a dar sentido ao 'mundo sensível'. O sentido é algo que se dá; ele acontece". ${ }^{131}$

\section{A jurisprudência dos valores}

Com o fim da Segunda Guerra Mundial e o assombro quanto à impotência do direito para evitar a solução final posta em curso pelo nacionalsocialismo alemão, voltaram-se os teóricos jurídicos para o desenvolvimento de uma teoria que superasse o positivismo jurídico avalorativo, exatamente mediante a busca de justificação da validade das normas em valores superiores ao direito positivo.

Nas palavras de Karl Larenz "o Direito é uma parte da cultura; a cultura é uma realidade referida a valores; o Direito é, portanto, uma realidade determinada, em sua peculiaridade, pela referência ao valor especificamente jurídico, a justiça". ${ }^{132}$

porém frente a uma só operação. Interpretação e aplicação consubstanciam um processo unitário, se superpõem" (Ensaio e Discurso sobre a Interpretação/ Aplicação do Direito, 2002, p. 76). Ver também: STRECK, Lenio Luiz, O Efeito Vinculante das Súmulas e o Mito da Efetividade: Uma Crítica Hermenêutica, 2005, p. 162; TORRES, Ricardo Lobo, Normas de Interpretação e Integração do Direito, 2006, p. 61.

131 STRECK, Lenio Luiz. Jurisdição Constitucional e Hermenêutica: Uma Nova Crítica do Direito. 2. ed. Rio de Janeiro: Forense, 2004. p. 32.

132 LARENZ, Karl. La Filosofía Contemporánea del Derecho y del Estado. Tradução E. Galán Gutiérrez; A. Truyol Serra. Madrid: Editorial Revista de Derecho Privado, 1942. p. 98. A jurisprudência valorativa de Larenz se reflete em sua definição de princípios jurídicos, constante na passagem a seguir: "Os princípios jurídicos são os pensamentos diretores de uma regulação jurídica existente ou possível. Em si mesmos, não são, todavia, regras suscetíveis de aplicação, mas podem transformar-se em regras. Quando remetem a um conteúdo intelectivo que conduz a uma regulação, são princípios 'materiais', ainda que lhes falte, todavia, o caráter formal de proposições jurídicas, representando a conexão entre um 'pressuposto de fato' e uma 'conseqüência jurídica'. Os princípios indicam apenas a direção na qual está situada a regra que deve ser encontrada. Podemos dizer que são um primeiro passo para a obtenção da regra, que determina os passos posteriores. Como ao estabelecer as regras de comportamento humano se escolhe entre diferentes possibilidades e, para tanto, realiza-se uma valoração 
Representante dessa linha de pensamento foi o jusfilósofo alemão Gustav Radbruch (1878-1949), para quem “o direito só pode ser compreendido dentro da atitude que refere as realidades aos valores (wertbeziehend). $\mathrm{O}$ direito é um fato ou fenômeno cultural, isto é, um fato referido a valores". ${ }^{133}$

Em seus "Cinco Minutos de Filosofia", Radbruch sustenta que a validade do direito positivo não pode ser aferida tendo em vista apenas parâmetros formais. Com efeito, para o jurista alemão "há também princípios fundamentais de direito que são mais fortes do que todo e qualquer preceito jurídico positivo, de tal modo que toda a lei que os contrarie não poderá deixar de ser privada de validade". ${ }^{134}$

Uma teoria jurídica voltada à realização de valores implica uma reforma na própria forma de legislar, uma vez que se faz necessária uma maior abertura dos textos legais com a delegação de maior atribuição ao julgador para ponderar os valores em jogo em cada caso concreto.

Torna-se então cada vez mais comum a utilização nos textos legais de conceitos indeterminados e tipos, os quais impõem uma mudança na própria forma mediante a qual os operadores jurídicos devem examinar o fenômeno hermenêutico.

A jurisprudência dos valores, na medida em que impõe uma interpretação jurídica que não se limita ao direito positivo, impõe a ponderação de valores extrajurídicos. Como destaca Karl Larenz, "a passagem a uma ‘jurisprudência de valoração’ só cobra, porém, o seu pleno sentido quando conexionada na maior parte dos autores com o reconhecimento de valores ou critérios de valoração 'supralegais' ou 'pré-positivos' que subjazem às normas legais e para cuja interpretação e complementação é legítimo lançar mão, pelo menos sob determinadas condições". ${ }^{135}$ O sistema jurídico seria então, segundo Canaris, uma ordenação axiológica. ${ }^{136}$

- este se estima mais do que outro -, os princípios contém pré-decisões sobre os valores posteriores que se tem que encontrar e que se têm que manter dentro do marco assinalado pela pré-decisão, que deve dar satisfação ao princípio" (LARENZ, Karl. El Derecho Justo. Tradução Luis Díes-Picazo. Madrid: Civitas, 2001. p. 32-33).

133 RADBRUCH, Gustav, Filosofia do Direito, 1997, p. 45.

134 RADBRUCH, Gustav, Filosofia do Direito, 1997, p. 45.

135 LARENZ, Karl, Metodologia da Ciência do Direito, 1997, p. 167.

136 CANARIS, Claus-Wilhelm. Pensamento Sistemático e Conceito de Sistema na Ciência do Direito. 2.ed. Tradução A. Menezes Cordeiro. Lisboa: Fundação Calouste Gulbenkian, 1996. p. 66-67. 
Questão relevante no campo da jurisprudência dos valores consiste na fundamentação da decisão judicial. De fato, considerando que, como dito, as valorações partem de aspectos não auferíveis pela lógica subsuntiva, impõe-se então o desenvolvimento de novas fórmulas de justificação das decisões judiciais, como a tópica e a teoria da argumentação.

\section{O pós-positivismo}

O termo pós-positivismo não designa uma corrente uniforme de pensamento, referindo-se às correntes jurídicas contemporâneas decorrentes dessa reaproximação entre direito e valores. ${ }^{137}$

Um dos marcos desse pensamento voltado a valores é a teoria da justiça de John Rawls (1921-2002).

A teoria da justiça de John Rawls, cujo refinamento teórico impõe redobrada cautela ao se expor seus fundamentos de forma concisa é, em linhas gerais, uma tentativa de se estabelecer critérios para uma justiça pública, relativos à estrutura básica da sociedade, ${ }^{138}$ a qual somente pode ser aplicável a uma sociedade bem ordenada ${ }^{139}$ (com regras institucionalizadas democraticamente). Caracteriza-se por ser uma teoria contratualista, determinando que os princípios fundamentais de justiça devem ser pactuados, em uma posição original de igualdade, por pessoas racionais e razoáveis, as quais, protegidas por um véu de ignorância, estariam aptas a estabelecer tais princípios de forma eqüitativa. ${ }^{140}$ Por seu turno, tais pessoas tenderiam a estabelecer, na posição original, dois princípios distintos: um que garantisse as liberdades fundamentais a todos e outro que previsse que as desigualdades entre os homens somente seriam justas na medida em que beneficiassem os menos favorecidos, e que as oportunidades sociais e econômicas deveriam

137 Cf. TORRES, Ricardo Lobo. Tratado de Direito Constitucional

Financeiro e Tributário: Valores e Princípios Constitucionais Tributários. Rio de Janeiro: Renovar, 2005. p. 57; CALSAMIGLIA, Albert. Postpositivismo. Doxa. Cuadernos de Filosofía del Derecho, Alicante, n. 21, 1998, p. 209, CAMARGO, Maria Margarida Lacombe. Eficácia Constitucional: Uma Questão Hermenêutica. In: BOUCALT, Carlos E. de Abreu; RODRIGUEZ ， José Rodrigo (Coords.). Hermenêtica Plural. São Paulo: Martins Fontes, 2002. p. 377.

138 RAWLS, John. A Theory of Justice. Cambridge: Harvard University Press, 2001. p. 6 e 7.

139 RAWLS, John, A Theory of Justice, 2001, p. 397 - 405.

140 RAWLS, John, A Theory of Justice, 2001, p. 102-160. 
ser isonomicamente acessíveis. ${ }^{141}$

A teoria de Rawls é basicamente uma teoria de justiça distributiva, a partir da qual se busca estabelecer mecanismos para distribuir os bens coletivos de forma isonômica entre todos, de forma que todos devem ter iguais oportunidades para atingir as posições socialmente vantajosas, redistribuindo-se pela coletividade as vantagens gozadas arbitrariamente por determinados sujeitos (dons naturais e posições originárias de vantagem).

$\mathrm{O}$ ressurgimento das relações direito-moral-justiça, impulsionam, portanto, a teoria jurídica do pós-positivismo, como apontam Luís Roberto Barroso e Ana Paula de Barcellos. ${ }^{142}$

Nessa mesma linha de idéias, ressalta Maria Margarida Lacombe Camargo que

[...]o pós-positivismo, como movimento de reação ao modelo Kelseniano de negação dos valores, abre-se a duas vertentes. Uma delas, que segue

141 RAWLS, John, A Theory of Justice, 2001, p. 53.

142 Em textual: "A superação histórica do jusnaturalismo e o fracasso político do positivismo abriram caminho para um conjunto amplo e ainda inacabado de reflexões acerca do Direito, sua função social e sua interpretação. O pós-positivismo é a designação provisória e genérica de um ideário difuso, no qual se incluem a definição das relações entre valores, princípios e regras, aspectos da chamada nova hermenêutica constitucional, e a teoria dos direitos fundamentais, edificada sobre o fundamento da dignidade humana. A valorização dos princípios, sua incorporação, explícita ou implícita, pelos textos constitucionais e o reconhecimento pela ordem jurídica de sua normatividade fazem parte desse ambiente de reaproximação entre Direito e Ética" (BARROSO, Luís Roberto; BARCELLOS, Ana Paula de. O começo da história. A nova interpretação constitucional e o papel dos princípios no direito brasileiro. In: BARROSO, Luís Roberto (Org.). A Nova Interpretação Constitucional: Ponderação, Direitos Fundamentais e Relações Privadas. Rio de Janeiro: Renovar, 2003. p. 336). Nas palavras de Marcus Abraham: "O pós-positivismo reintroduz no ordenamento jurídico positivo as idéias de justiça e legitimidade, através do constitucionalismo moderno, com o retorno aos valores e com a reaproximação entre moral, ética e o direito, materializados em princípios jurídicos abrigados na Constituição, que passam a ter maior efetividade normativa, influenciando sobremaneira a teoria da interpretação do direito e, inclusive, do direito tributário" (ABRAHAM, Marcus. $O$ Planejamento Tributário e o Direito Privado. São Paulo: Quartier Latin, 2007. p. 96). 
a linha de Dworkin e Alexy, busca recuperar a força normativa dos princípios de direito, com todo seu potencial valorativo. A outra procura, nos fundamentos que sustentam as decisões judiciais, sua força lógico-legitimante, como faz Chaïm Perelman, por exemplo. ${ }^{143}$

Característica, portanto, do pós-positivismo é a valorização dos princípios jurídicos, principalmente a partir dos aportes de Ronald Dworkin $^{144}$ (1931- ) e Robert Alexy (1945- ) e suas teorias para a distinção entre princípios e normas.

Para Ronald Dworkin, princípio é "um padrão que deve ser observado, não porque irá alcançar ou assegurar uma situação econômica, política, ou social supostamente desejada, mas porque é uma exigência de justiça ou eqüidade, ou alguma outra dimensão de moralidade". ${ }^{145}$

Já segundo Robert Alexy,

[...] o ponto decisivo para a distinção entre regras e princípios é que os princípios são normas que ordenam que algo seja realizado na maior medida possível, dentro das possibilidades jurídicas e reais existentes. Portanto, os princípios são mandados de otimização, que estão caracterizados pelo fato de que podem ser cumpridos em diferente grau e que a medida devida de seu cumprimento não só depende das possibilidades reais mas também das jurídicas. O âmbito das possibilidades jurídicas é determinado pelos princípios e regras opostas. ${ }^{146}$

143 CAMARGO, Maria Margarida Lacombe, Hermenêutica Jurídica e Argumentação: Uma Contribuição ao Estudo do Direito, 2001, p. 141.

144 Interessante a observação de Albert Calsamiglia, quando aponta que a obra de Ronald Dworkin seria o primeiro grande ataque à Escola Analítica de Austin, depurada no positivismo light de Herbert Hart (CALSAMIGLIA, Albert. ¿Por que es Importante Dworkin? Doxa. Cuadernos de Filosofía del Derecho, Alicante, n. 2, 1985, p. 159-161.

145 DWORKIN, Ronald. Taking Rights Seriously. Cambridge: Harvard University Press, 1999. p. 22.

146 ALEXY, Robert. Teoria de los Derechos Fundamentales. Tradução 
Partindo dessas e outras idéias, Humberto Ávila forjou sua definição de princípios jurídicos, os quais seriam

[...] normas imediatamente finalísticas, primariamente prospectivas e com pretensão de complementariedade e de parcialidade, para cuja aplicação demandam uma avaliação da correlação entre o estado de coisas a ser promovido e os efeitos decorrentes da conduta havida como necessária à sua promoção. ${ }^{147}$

Tendo os princípios jurídicos, positivados ou não, como diretrizes a serem alcançadas pelo direito, busca-se superar as limitações do positivismo jurídico, tão criticado por Dworkin. ${ }^{148}$

É pertinente aqui o comentário de Albert Calsamiglia, para quem o

[...] pós-positivismo põe atenção sobre a pergunta que se deve fazer ante a um caso difícil. A resposta do positivismo era acudir ao legislador intersticial. Mas quando o raciocínio judicial se efetua fora do domínio do direito encontramo-nos em terra incógnita. Não deixa de ser curioso que quando mais necessitamos orientação, a teoria positivista emudece. ${ }^{149}$

Nada obstante, não se pode ter a falsa idéia de que o próprio positivismo jurídico não pode lidar com a revolução principiológica.

Nesse sentido é a lição de Neil MacCormick, que vem trabalhando com os princípios jurídicos dentro de uma perspectiva positivista.

Para MacCormick, "os princípios de um sistema jurídico são as

Ernesto Garzón Valdés. Madrid: Centro de Estudios Políticos y Constitucionales, 2001. p. 86.

147 ÁVILA, Humberto. Teoria dos Princípios: da definição à aplicação dos princípios jurídicos. São Paulo: Malheiros, 2003. p. 70.

148 DWORKIN, Ronald. Law's Empire. Cambridge: Harvard University Press, 1999.

149 CALSAMIGLIA, Albert, Postpositivismo, 1998, p. 212. 
normas gerais conceitualizadas por meio das quais funcionários racionalizam as normas que pertencem ao sistema em virtude de critérios observados internamente". ${ }^{150}$

Segundo o professor catedrático da Universidade de Edimburgo, "o princípio estabelece o limite dentro do qual são legítimas decisões judiciais plenamente justificadas por argumentos conseqüencialistas. Sua existência torna possível que um juiz chegue a uma decisão que, de outro modo, deveria caber à legislatura". ${ }^{151}$

Todavia, conforme mencionado anteriormente, a reaproximação entre direito e os valores, com a superação da lógica subsuntiva, traz problemas de justificação e legitimação da interpretação/aplicação do direito pelos tribunais, que necessitam demonstrar as razões e motivos de suas valorações. Sobre a questão podemos destacar como contribuições importantes para a nova forma de compreensão do direito tanto a tópica, de Theodor Viehweg, ${ }^{152}$ quando a teoria da argumentação jurídica, as quais serão examinadas a seguir.

\subsection{O pensamento por problemas: A tópica de Theodor Viehweg}

O pensamento tópico, que remonta a Cícero e Aristóteles, ressurgiu da década de 50 como uma alternativa ao formalismo jurídico e o raciocínio lógico-dedutivo, encontrando seu maior expoente na figura de Theodor Viehweg (1907-1988). ${ }^{153}$

Posta por terra a crença na possibilidade de se extrair comandos 150 MacCORMICK, Neil. Argumentação Jurídica e Teoria do Direito. Tradução Waldéa Barcellos. São Paulo: Martins Fontes, 2006. p. 201.

151 MacCORMICK, Neil, Argumentação Jurídica e Teoria do Direito, 2006, p. 209.

152 Conforme salienta Paulo Bonavides, "a tópica tem que ser compreendida portanto no quadro das conseqüências advindas da reação ao positivismo jurídico clássico e no clima de inteira descrença quanto a uma reestruturação jusnaturalista, como a que se intentou na Alemanha no fim da década de 40, após as feridas abertas na consciência do Ocidente pela tragédia da Segunda Grande Guerra Mundial" (BONAVIDES, Paulo. Curso de Direito Constitucional. 13. ed. São Paulo: Malheiros, 2003. p. 497). No mesmo sentido: BUSTAMANTE, Thomas da Rosa de. Tópica e argumentação jurídica. Revista de Informação Legislativa, Brasília, n. 163, jul.-set. 2004, p. 154-155.

153 Ver: VIEHWEG, Theodor. Tópica e Jurisprudência. Tradução Tercio Sampaio Ferraz Jr. Brasília: Departamento de Imprensa Nacional, 1979. 
normativos verdadeiros e desvinculados dos fatos em causa por intermédio da lógica dedutiva, com o ressurgimento dos valores e dos princípios jurídicos, torna-se necessária a discussão de uma forma de pensar o direito que dê conta não apenas do texto normativo, mas de todos os elementos que influenciam a decisão do órgão de aplicação do direito. Esse é, exatamente, o papel da tópica jurídica, a qual é muito bem descrita por Antonio Manuel Hespanha:

A tópica é, como já se disse, o nome dado pela antiga teoria do discurso à técnica de encontrar soluções no domínio dos saberes problemáticos, ou seja, dos saberes em que não existem certezas evidentes, como o direito, a moral, etc. Nestes casos, a legitimação da solução encontrada não decorre tanto da validade das premissas em que esta se baseia como no consenso que suscitou no auditório. Aplicada ao direito, esta idéia vem a colocar o juiz (ou o jurista) na primeira linha da atividade de achamento ou de declaração do direito, o qual, para decidir um caso concreto, lança mão de argumentos (tópicos) disponíveis (princípios doutrinais, precedentes, disposições legislativas), no sentido de ganhar o assentimento (das partes, mas também do público em geral) para a solução. Neste contexto, a lei é apenas um dos argumentos, cuja eficácia argumentativa dependerá tanto da sua consonância com o sentido concreto de justiça vigente no auditório como do prestígio de que a forma "lei" (e, em geral, a entidade "Estado") aí goze. Para além de constituir uma crítica ao legalismo, a tópica constitui também uma crítica ao normativismo, ou seja, à idéia de que a norma geral e abstrata está no princípio de um processo de subsunção que conduziria ao achamento do direito. Pelo contrário, a tópica defende que é o caso, com o seu caráter concreto e situado, que sugere os argumentos ou pontos de vista relevantes, bem 
como que os permite hierarquizar. ${ }^{154}$

Como pontua José de Oliveira Ascenção a tópica procura chegar a "um repertório de pontos de vista que darão a solução de casos concretos". ${ }^{155}$

Para Chaïm Perelman

[...] a importância dos lugares específicos do direito, isto é, dos tópicos jurídicos, consiste em fornecer razões que permitem afastar soluções não eqüitativas ou desarrazoadas, na medida em que estas negligenciam as considerações que os lugares permitem sintetizar e integrar em uma visão global do direito como ars aequi et boni. ${ }^{156}$

Segundo Viehweg:

A função dos topoi, tanto gerais como especiais, consiste em servir a uma discussão de problemas. Segue-se daí que sua importância tem que ser muito especial naqueles círculos de problema

154 HESPANHA, António Manuel, Cultura Jurídica Européia: Síntese de um Milénio, 2003, p. 338-339. Leciona Tercio Sampaio Ferraz Jr. que "quando se fala, hoje, em tópica pensa-se, como já dissemos, numa técnica de pensamento que se orienta para problemas. Trata-se de um estilo de pensar e não, propriamente, de um método. Ou seja, não é um conjunto de princípios de avaliação da evidência nem de cânones para julgar a adequação de explicações propostas, nem ainda critério para selecionar hipóteses. Em suma, não se trata de um procedimento verificável rigorosamente. Ao contrário, é um modo de pensar, problemático, que nos permite abordar problemas, deles partir e neles culminar. Assim, pensar topicamente significa manter princípios, conceitos, postulados com caráter problemático visto que jamais perdem sua qualidade tentativa. Veja, por analogia, o que acontece com a elaboração de um dicionário, em que muitos verbetes, pela diversidade de acepções, exigem abordagens, que, partindo de distintos pontos de vista, não fecham nem concluem, embora dêem a possibilidade de compreender a palavra em sua amplitude (problemática)" (FERAZ JR., Tercio Sampaio, Introdução ao Estudo do Direito, 2001, p. 323-324).

155 OLIVEIRA ASCENÇÃO, José de, Introdução à Ciência do Direito, 2005, p. 464.

156 PERELMAN, Chaïm, Lógica Jurídica, 2000, p. 120. 
em cuja natureza está não perder nunca o seu caráter problemático. Quando se produzem mudanças de situações e em casos particulares, é preciso encontrar novos dados para tentar resolver os problemas. Os topoi, que intervêm com caráter auxiliar, recebem por sua vez sentido a partir do problema. A ordenação com respeito ao problema é sempre essencial para eles. À vista de cada problema aparecem como adequados ou inadequados, conforme um entendimento que nunca é absolutamente imutável. Devem ser entendidos de um modo funcional, como possibilidades de orientação e como fios condutores do pensamento. ${ }^{157}$

Tal repertório de pontos de vista, de topoi, é sempre provisório e cambiante em função do problema. Como destaca Viehweg, "a tópica não pode ser entendida se não se admite a sugerida inclusão em uma ordem que está sempre por ser determinada". ${ }^{158}$

Portanto, pode-se caracterizar a tópica como uma forma de pensar em função do problema. ${ }^{159}$ Nas palavras de Viehweg,

157 VIEHWEG, Theodor, Tópica e Jurisprudência, 1979, p. 38.

158 VIEHWEG, Theodor, Tópica e Jurisprudência, 1979, p. 35. Sobre a necessidade de abertura e flexibilidade dos topoi, vale a pena destacar outra passagem de Viehweg, onde afirma que "os topoi e os catálogos de topoi oferecem um auxílio muito apreciável. Porém, o domínio do problema exige flexibilidade e capacidade de alargamento" (VIEHWEG, Theodor, Tópica e Jurisprudência, 1979, p. 41).

159 Nas palavras de Manuel Atienza, "a tópica é (de acordo com a distinção de Cícero aludida anteriormente) uma ars inveniende, um procedimento de busca de premissas (de tópicos) que, na realidade, não termina nunca: o repertório de tópicos sempre é necessariamente provisório, elástico. Os tópicos devem ser entendidos de um modo funcional, como possibilidades de orientação e como fios condutores do pensamento que só permitem alcançar conclusões curtas. A isso se contrapõe a ars iudicandi, a lógica demonstrativa que recebe premissas e trabalha com elas, o que permite a elaboração de longas cadeias dedutivas" (ATIENZA, Manuel. As Razões do Direito: Teorias da Argumentação Jurídica. Tradução Maria Cristina Guimarães Cupertino. São Paulo: Landy, 2002. p. 66). Ver também: MAIA, Antônio Cavalcanti. A importância da dimensão argumentativa 
[...] o sistema tópico está em permanente movimento. Suas formulações respectivas indicam meramente os estágios progressivos da argumentação ao tratar de problemas particulares. O sistema pode razoavelmente ser chamado um sistema aberto, já que sua discussão, quer dizer, seu enfoque de um problema particular, está aberta a novos pontos de vista. ${ }^{160}$

Para um melhor entendimento da tópica é importante a caracterização do problema. Segundo Viehweg:

Para nosso fim, pode chamar-se problema - esta definição basta - toda questão que aparentemente permite mais de uma resposta e que requer necessariamente um entendimento preliminar, de acordo com o qual toma o aspecto de questão que há que levar a sério e para a qual há que buscar uma resposta como solução. [...]. ${ }^{161}$

Como bem notado por Paulo Roberto Soares de Mendonça, as soluções dadas aos problemas podem ser agrupadas em catálogos de soluções, compondo assim um sistema a partir do qual venham a ser solucionados os problemas no futuro. O pensamento tópico funciona de forma inversa, questionando sempre as premissas e extraindo novos pontos de vista a partir dos problemas. ${ }^{162}$

Nota-se, portanto, que, como salienta Thomas da Rosa de Bustamante,

à compreensão da práxis contemporânea. Revista Trimestral de Direito Civil, Rio de Janeiro, v. 8, out.-dez. 2000, p. 271-272; GARCÍA AMADO, Juan Antonio. Tópica, Derecho y Método Jurídico. Doxa. Cuadernos de Filosofía del Derecho, Alicante, n. 4, 1987, p. 162; BONAVIDES, Paulo, Curso de Direito Constitucional, 2003, p. 490-491.

160 VIEHWEG, Theodor. Algunas Consideraciones acerca del Razonamiento Jurídico. In: Tópica y Filosofia del Derecho. Tradução Jorge M. Seña. Barcelona: Gedisa, 1997. p. 127.

161 VIEHWEG, Theodor, Tópica e Jurisprudência, 1979, p. 34.

162 MENDONÇA. Paulo Roberto Soares de. A Tópica e o Supremo Tribunal Federal. Rio de Janeiro: Renovar, 2003. p. 100. 
"o papel central da tópica é encontrar as premissas que serão utilizadas no raciocínio". 163

A tópica abre o pensamento jurídico para além do texto normativo, o qual figura como mais um tópico a ser levando em consideração, o tópico de partida, mas, como adverte Juan Antonio García Amado, "por sua generalidade, a rigidez de sua forma e sua textura aberta, precisa ser concretizado mediante outros tópicos que determinem seus sentidos possíveis e façam viável a discussão tendente a obter o significado que melhor se adeqüe à realidade de cada caso a resolver". ${ }^{164}$

É de se assinalar, com Luiz Alberto Warat, que "a tópica não assegura decisões certas e incontrovertíveis, mas dá soluções aceitáveis dentro do marco da ideologia que adota. Admite a alterabilidade significativa da lei, que origina a problemática interpretativa e decisória". ${ }^{165}$

O próprio Viehweg alertava para o fato de que a tópica "não é um método, mas sim um estilo. Ela tem, como qualquer outro estilo, muito de arbítrio amorfo e muito pouco de demonstração". ${ }^{166}$

\subsection{A teoria da argumentação}

As teorias de argumentação encontram-se inseridas nesse contexto de questionamento da lógica formal como forma de realização concreta do direito, aproveitando da tópica a inserção dos fatos (do problema) no processo de criação jurídica. Conforme salienta Maria Margarida Lacombe 163 BUSTAMANTE, Thomas da Rosa de, Tópica e argumentação jurídica, 2004, p. 159.

164 GARCÍA AMADO, Juan Antonio, Tópica, Derecho y Método Jurídico, 1987, p. 174. Ver, ainda: CRISTÓVAM, José Sérgio da Silva. Colisões entre Princípios Constitucionais. Curitiba: Juruá: 2006. p. 129.

165 WARAT, Luiz Alberto, Introdução Geral ao Direito, 1994, p. 88. Há que se concordar com as ponderações de Antonio Nedel, quando afirma que o que "parece mais importante ressaltar no que concerne à tópica jurídica não são os topoi e o fundamento metafísico que eles suscitam, mas, sim, o caráter dialético e as possibilidades crítico-criativas que a sua índole retórico argumentativa propicia, enquanto método de resolução dos concretos problemas jurídicos, elevando, como o valor mais relevante do direito, a prospeç̧ão dialógica que pode conduzir, no âmbito das controvérsias, sua elucidação racional-consensual" (NEDEL, Antônio. Uma Tópica Jurídica: clareira para a emergência do direito. Porto Alegre: Livraria do Advogado, 2006. p. 222).

166 VIEHWEG, Theodor, Tópica e Jurisprudência, 1979, p. 71. 
Camargo:

Procuramos também destacar a dimensão concreta própria do pensar jurídico, orientado que é para o problema que se pretende resolver. Coube a Chaïm Perelman realizar a grande guinada na área da metodologia jurídica, quando apontou para as dimensões retórica e argumentativa que, na realidade, fazem o direito. $\mathrm{O}$ direito originase da prática; não se limita ao conteúdo do texto da lei: surge e é orientado pelas teses construídas sob os parâmetros do fato e da lei, num confronto de idéias que vêm legitimar cada decisão tomada de per si. Ressaltamos, assim, algumas das contribuições mais significativas para a reflexão jurídica contemporânea, avessa à adoção do raciocínio lógico-linear para, em lugar desta, uma proposta mais voltada para a intersubjetividade e para o desafio constante de lidar com situações que requerem respostas convincentes e criativas. ${ }^{167}$

Uma das críticas voltadas contra a tópica jurídica consiste em não fornecer a mesma um método para a utilização dos diversos tópicos jurídicos, sendo mais uma forma de pensar do que uma metodologia que possa substituir a lógica formal. Como vimos, o próprio Viehweg negava à tópica o caráter de método jurídico. ${ }^{168}$ As teorias de argumentação diferem da tópica por terem por fim a apresentação de uma nova metodologia jurídica.

Essa é a posição de Manuel Atienza, que ao analisar a função prática da argumentação jurídica afirma:

Por função prática ou técnica da argumentação jurídica, entendo basicamente que esta deve ser capaz de oferecer uma orientação útil nas tarefas de produzir, interpretar e aplicar o Direito. Para que uma teoria da argumentação jurídica possa

167 CAMARGO, Maria Margarida Lacombe, Hermenêutica Jurídica e Argumentação: Uma Contribuição ao Estudo do Direito, 2001, p. 262.

168 VIEHWEG, Theodor, Tópica e Jurisprudência, 1979, p. 71. 
cumprir essa função de caráter instrumental (dirigida tanto aos práticos do Direito como aos cultivadores da dogmática jurídica) ela terá de poder oferecer um método que permita reconstruir o processo real da argumentação, além de uma série de critérios para fazer um julgamento sobre a sua correção; como se acaba de indicar, essa é uma tarefa que, em considerável medida, ainda está para ser cumprida. ${ }^{169}$

Entendo que a argumentação não pode ser vista como um método jurídico a partir do qual seja possível atestar a correção das decisões jurídicas, sendo, isso sim, uma forma de pensar o direito que leva à tomada de decisões justificáveis, a qual é especialmente necessária nas situações em que o texto, por si só, é vago e ambíguo. ${ }^{170}$

Nessa linha, Neil MacCormick sustenta que o dever judicial de fazer justiça é o dever de proferir decisões que sejam fundamentadas em argumentos satisfatórios. ${ }^{171} \mathrm{O}$ arbítrio judicial seria, portanto, "um arbítrio de proferir a decisão que seja mais bem justificada". ${ }^{172}$

Segundo Chaïm Perelman, "motivar uma sentença é justificá-la, não é fundamentá-la de um modo impessoal e, por assim dizer, demonstrativo. É persuadir um auditório, que se deve conhecer, de que a decisão é conforme às suas exigências". 173

Já que busca a adesão dos destinatários da decisão à mesma, a

169 ATIENZA, Manuel, As Razões do Direito: Teorias da Argumentação Jurídica, 2002, p. 333.

170 Conforme destaca Humberto Ávila, “[...] Uma teoria jurídica da argumentação não se confunde com uma teoria racional da argumentação, que opta, entre os argumentos que podem ser utilizados, pelo mais racional, plausível ou sustentável. Uma teoria jurídica da argumentação procura fundamentar no próprio ordenamento jurídico a escolha entre os argumentos" (ÁVILA, Humberto. Sistema Constitucional Tributário. São Paulo: Saraiva, 2004. p. 203).

171 MacCORMICK, Neil, Argumentação Jurídica e Teoria do Direito, 2006, p. 326.

172 MacCORMICK, Neil, Argumentação Jurídica e Teoria do Direito, 2006, p. 327.

173 PERELMAN, Chaïm. Ética e Direito. Tradução Maria Emantina Galvão. São Paulo: Martins Fontes, 2002. p. 569-570. 
argumentação jurídica deve se dar no âmbito do diálogo, permitindo a participação daqueles na formação desta. Sobre a adesão dos destinatários ao resultado da interpretação salienta Perelman que "a interpretação da lei, para ser aplicada a um caso específico, deve ser considerada uma hipótese, que só será adotada definitivamente se a solução concreta em que redunda afigurar-se aceitável". ${ }^{174}$

É no âmbito da argumentação que serão ponderados os bens, interesses e valores em jogo, de modo que somente em cada caso é que o texto normativo concretizar-se-á em norma jurídica individual e concreta. ${ }^{175}$

174 PERELMAN, Chaïm, Lógica Jurídica, 2000, p. 115. Em outra passagem, afirma Perelman que "em nítida oposição aos métodos da lógica formal, vimos que toda argumentação deve partir de teses que têm a adesão daqueles a que se quer persuadir ou convencer. Negligenciando esta condição, o orador, aquele que apresenta uma argumentação, arrisca-se a cometer uma petição de princípio" (PERELMAN, Chaïm, Lógica Jurídica, 2000, p. 158). Ver: GARCÍA AMADO, Juan Antonio, Tópica, Derecho y Método Jurídico, 1987, p. 174; CRISTÓVAM, José Sérgio da Silva, Colisões entre Princípios Constitucionais, 2006, p. 129; CRETTON, Ricardo Aziz. Os Princípios da Proporcionalidade e da Razoabilidade e sua Aplicação no Direito Tributário. Rio de Janeiro: Lúmen Júris, 2001. p. 38.

$175 \mathrm{O}$ debate quanto à ponderação foi introduzido no cenário jurídico nacional no âmbito da discussão quanto à solução da colisão entre princípios, notadamente quando o intérprete está diante dos chamados casos difíceis (Cf. SARMENTO, Daniel. A Ponderação de Interesses na Constituição Federal. Rio de Janeiro: Lumen Juris, 2002. p. 99). Como salienta Ana Paula de Barcellos, "de forma muito geral, a ponderação pode ser descrita como uma técnica de decisão própria para casos difíceis (do inglês hard cases), em relação aos quais o raciocínio tradicional da subsunção não é adequado" (BARCELLOS, Ana Paula de. Alguns Parâmetros Normativos para a Ponderação Constitucional. In: BARROSO, Luís Roberto (Org.). A Nova Interpretação Constitucional: Ponderação, Direitos Fundamentais e Relações Privadas. Rio de Janeiro/São Paulo: Renovar, 2003. p. 55).Todavia, como destaca a própria Ana Paula, "já é possível identificá-la [a ponderação] como uma técnica de decisão jurídica autônoma que, aliás, vem sendo aplicada em diversos outros ambientes que não o do conflito entre princípios" (BARCELLOS, Ana Paula de, Alguns Parâmetros Normativos para a Ponderação Constitucional, 2003, p. 56). Nas palavras de Humberto Ávila, “a ponderação não é método privativo de aplicação dos princípios. A ponderação ou balanceamento (weighing and balancing Abwägung), enquanto sopesamento de razões e contrarazões que culmina com a decisão de interpretação, também pode estar presente no caso de dispositivos hipoteticamente formulados, cuja aplicação é preliminarmente havida como automática (no caso de regras, consoante o critério aqui investigado), 
Na medida em que a teoria do pós-positivismo tem trabalhado com a teoria da argumentação e a justificação das decisões pelo juiz, verifica-se, como ressalta Calsamiglia, a mudança do centro das atenções do Legislativo para o Judiciário. ${ }^{176}$

Como mencionado, não há uma teoria da argumentação, mas teorias de argumentação, podendo-se destacar, entre os autores que trabalham com a argumentação jurídica, Robert Alexy, ${ }^{177}$ Klaus Günther, ${ }^{178}$ Chaïm Perelman ${ }^{179}$ e Stephen Toulmin. ${ }^{180}$

\section{Síntese conclusiva}

Ao fim dessa análise da evolução histórica do pensamento jurídico a partir dos formalismos do século XVIII, chega-se à conclusão de que a hermenêutica contemporânea se desprendeu das balizas impostas pela jurisprudência conceitual e as escolas analítica e exegética.

Hodiernamente mesmo positivistas como Herbert Hart acolhem a influência dos valores sobre o direito, reconhecendo-se, portanto, o caráter axiológico do processo hermenêutico.

como se comprova mediante a análise de alguns exemplos" (ÁVILA, Humberto, Teoria dos Princípios: da definição à aplicação dos princípios jurídicos, 2003, p. 44). Sobre a ponderação como postulado hermenêutico, ver: BARROSO, Luís Roberto. O Começo da História. Nova Interpretação Constitucional e o Papel dos Princípios no Direito Brasileiro. In: BARROSO, Luís Roberto (Org.). A Nova Interpretação Constitucional: Ponderação, Direitos Fundamentais e Relações Privadas. Rio de Janeiro/São Paulo: Renovar, 2003. p. 344-350; CANOTILHO, J. J. Gomes. Direito Constitucional e Teoria da Constituição. 3. ed. Coimbra: Almedina, [s/d]. p. 1161-1165; BARCELOS, Ana Paula. Ponderação, Racionalidade e Atividade Jurisdicional. Rio de Janeiro: Renovar, 2005.

176 Cf. CALSAMIGLIA, Albert, Postpositivismo, 1998, p. 215.

177 ALEXY, Robert. Teoria da Argumentação: A Teoria do Discurso Racional como Teoria da Justificação Jurídica. Tradução de Zilda Hutchinson Schild Silva. São Paulo: Landy, 2001.

178 GÜNTHER, Klaus. Teoria da Argumentação no Direito e na Moral: Justificação e Aplicação. Traducão Cláudio Molz. São Paulo: Landy, 2004. 179 PERELMAN, Chaïm; OLBRECHTS-TYTECA, Lucie. Tratado da Argumentação. Tradução Maria Ermantina Galvão. São Paulo: Martins Fontes, 2000 ; .

180 TOULMIN, Stephen. Os Usos do Argumento. Tradução Reinaldo Guarany. São Paulo: Martins Fontes, 2001. 
Foi superado também o objetivismo metodológico de algumas correntes formalistas, que pretendiam que o intérprete encontrasse no texto legal uma única norma verdadeira que seria alcançada pela aplicação dos métodos interpretativos, normalmente derivações dos elementos da interpretação apresentados por Savigny.

Com efeito, a partir dos aportes de Hans-Georg Gadamer tornouse evidente que o processo hermenêutico se dá no intérprete, de forma que não se pode segregar este do texto interpretado e do objeto sobre o qual se "aplicaria" o direito, como se as normas fossem uma massa de concreto trabalhada pelo intérprete e aplicada sobre os tijolos na construção de uma decisão.

Essa nova colocação da questão tornou relevante a situação do intérprete, passando a ter destaque o exame da sua pré-compreensão, a partir de sua inserção em uma cultura que afeta sua vida hermenêutica. ${ }^{181}$

Por outro lado, a inevitável abertura da linguagem, ${ }^{182}$ que torna letra morta o objetivismo metodológico antes pretendido, aliado à transferência do problema hermenêutico para o intérprete, o qual se encontra inserido numa determinada cultura, ${ }^{183}$ que afeta a sua pré-compreensão, e à prevalência

181 Segundo Wilson Engelmann: “A pré-compreensão é a responsável pela antecipação do sentido das coisas que nos circundam no mundo. Entre a compreensão, como parte integrante do processo de interpretação, e a précompreensão estabelece-se a configuração de um círculo. Dito de outro modo, sempre existe um procedimento prévio já conhecido que se projeta sobre a compreensão e vice-versa. [...]" (ENGELMANN, Wilson. Direito Natural, Ética e Hermenêtica. Porto Alegre: Livraria do Advogado, 2006. p. 221.

182 Ver: CARRIÓ, Genaro R. Notas sobre Derecho y Lenguage. 4. ed. Buenos Aires: Abeledo-Perrot, 1994. p. 31; ALCHOURRÓN, Carlos R.; BULYGIN, Eugenio. Introducción a la Metodología de las Ciencias Jurídicas y Sociales. Buenos Aires: Editorial Astrea, 2002. p. 62-65; HART, H. L. A.,The Concept of Law, 1997, p. 129; STRUCHINER, Noel, Direito e Linguagem: Uma Análise da Textura Aberta da Linguagem e sua Aplicação ao Direito, 2002, p. 68; ROSS, Alf, Direito e Justiça, 2000, p. 167 ANDRADE, José Maria Arruda de, Interpretação da Norma Tributária, 2006, p. 81-90; BASTOS, Celso Ribeiro. Hermenêutica e Interpretação Constitucional. 2. ed. São Paulo: Celso Bastos Editor, 1999. p. 28-29; GRECO, Marco Aurélio. Planejamento Fiscal e Interpretação da Lei Tributária. São Paulo: Dialética, 1998. p. 159.

183 Nas palavras de Rogério Gesta Leal, há que se ter em conta que "quem dá efetividade à interpretação é um ser racional e também histórico, que fala, se comunica dentro da história e de uma história determinada, de uma cultura 
dos valores, torna certamente possível que de um mesmo texto legal sejam extraídas normas jurídicas igualmente válidas, mas de distinto conteúdo. ${ }^{184}$

Conforme salienta Ricardo Guastini, "muitas disposições - talvez todas as disposições - têm um conteúdo de significado complexo: exprimem não apenas uma única norma, mas sim uma multiplicidade de normas associadas". 185

Trata-se aqui da discussão quanto à possibilidade de uma única resposta correta como resultado do processo de interpretação.

Embora importantes vozes, como a de Ronald Dworkin e, ${ }^{186}$

determinada, de um contexto determinado. Desta forma, o processo de constituição do significado do texto está profundamente marcado pelos elementos discursivos e categoriais erigidos pelo tempo daquela história" (LEAL, Rogério Gesta. Perspectivas Hermenêuticas dos Direitos Fundamentais no Brasil. Porto Alegre: Livraria do Advogado, 2000. p. 133).

184 É pertinente aqui a seguinte passagem de Joseph Raz: “A saída para esse impasse, a forma de reconciliar a existência de uma multiplicidade de interpretações que competem entre si com a objetividade, dirige-se à idéia que freqüentemente é posta metaforicamente dizendo que 'o significado do objeto não está no objeto'. A útil sugestão da metáfora é esta: se a interpretação depende de algo fora de seu objeto, então, possivelmente, há uma pluralidade de tais objetos adicionais, os quais dão conta da pluralidade de boas interpretações. O subjetivismo com sua pretensão de que qualquer interpretação se sustenta é, sem embargo, uma forma extremada de se entender a metáfora. De acordo com ela, a maneira que qualquer intérprete mira o objeto de interpretação, em qualquer tempo, como se expressa na interpretação, determina seu significado. Este é o porque todas as interpretações são igualmente boas quando são boas. Mas a metáfora mesma permite explicações mais sensatas que identificam outros fatores como os que determinam, em parte, os significados dos objetos, desta maneira determinam suas interpretações apropriadas” (RAZ, Joseph. ¿Por Qué Interpretar? Isonomía, México, n. 5, Out.-1996, p. 29-30).

185 GUASTINI, Ricardo. Das Fontes às Normas. Tradução Edson Bini. São Paulo: Quartier Latin, 2005. p. 35. Ver, também: GUASTINI, Ricardo. Teoria e Dogmatica delle Fonti. Milano: Giuffrè, 1998. p. 17; GRAU, Eros Roberto, Ensaio sobre a Interpretação/Aplicação do Direito, 2002, p. 30; GRAU, Eros Roberto. $O$ direito posto e o direito pressuposto. 3. ed. São Paulo: Malheiros, 2000. p. 153.

186 DWORKIN, Ronald, Taking Rights Seriously, 1999, p. 279-290.

Comentando a teoria de Dworkin, diz Wayne Morrison: "Talvez a mais controvertida das idéias associadas à obra inicial de Dworkin esteja em sua afirmação de que a prática jurídica envolve, necessariamente, a aceitação da idéia de haver sempre uma resposta certa aos dilemas jurídicos e morais. 
no Brasil, Lenio Streck, ${ }^{187}$ sustentem a possibilidade de se ter uma única resposta correta como resultado do processo hermenêutico, tal não parece refletir a natureza das normas jurídicas. ${ }^{188}$

Dworkin apresenta duas maneiras de se chegar a essa conclusão: (i) uma envolve a afirmação relativamente fraca de que, como a natureza do direito implica o envolvimento em litígios e sua solução, faz parte do raciocínio prático do direito o fato de que a resposta a um litígio deve ser clara - se disséssemos o tempo todo 'está empatado', a natureza prática das soluções jurídicas não teria sentido algum.; (ii) a outra consiste em procurar os pressupostos racionais envolvidos no próprio processo e nas próprias práticas de argumentação jurídica e política. Dworkin quer que consideremos em profundidade o que os advogados estão realmente fazendo em termos de prática nos casos difíceis, e nos pede para usar seu próprio discurso como ponto de partida. O direito parece incerto; não parece haver nenhuma resposta jurídica óbvia. Qual é, porém, a racionalidade dos diferentes aspectos das práticas sociais em questão? Vejamos um caso comum. As partes instruíram os advogados e talvez, depois de várias trocas de cartas, alegações e alegações em contrário, os dois lados decidem resolver a questão em juízo. Se os dois conjuntos de advogados estiverem agindo como agentes jurídicos sérios (isto é, se não estiverem às voltas com atos desnecessários), ambas as partes acreditam que estão certas em sua interpretação e sua crença de que o direito está do seu lado. $\mathrm{Na}$ verdade, ambas acreditam que há uma resposta a ser encontrada, e que se trata de uma resposta jurídica. Por que ir ao tribunal se você não acredita que seu lado é o certo? Isto é, que seus argumentos podem convencer o juiz a decidir que o direito é aquilo que você reivindica?" (MORRISON, Wayne. Filosofia do Direito: Dos Gregos ao Pós-modernismo. Tradução Jefferson Luiz Camargo. São Paulo: Martins Fontes, 2006. p. 505-506).

187 Cf. STRECK, Lenio Luiz. Verdade e Consenso: Constituição, Hermenêutica e Teorias Discursivas. Rio de Janeiro: Lumen Juris, 2006. p. 183195.

188 Nesse mesmo sentido, negando a possibilidade de se alcançar uma única resposta correta ao cabo da interpretação jurídica, ver: AARNIO, Aulis. Sobre la Ambigüedad Semántica en la Interpretación Jurídica. Doxa. Cuadernos de Filosofía del Derecho, Alicante, n. 4, 1987, p. 109-117; AARNIO, Aulis. La Tesis de la Única Respuesta Correcta y el Principio Regulativo del Razonamiento Jurídico. Doxa. Cuadernos de Filosofía del Derecho, Alicante, n. 8, 1990, p. 23-38; BARRAGÁN, Julia. La Respuesta Correcta Única y la Justificación de la Decisión Jurídica. Doxa. Cuadernos de Filosofía del Derecho, Alicante, n. 8, 1990, p. 6474; FARALLI, Carla. A Filosofia Contemporânea do Direito: Temas e Desafios. Tradução Candice Premaor Gullo. São Paulo: Martins Fontes, 2006. p. 46-47; KELSEN, Hans, Teoria Pura do Direito, 1984, p. 100-102; FREITAS, Juarez. A Melhor Interpretação Constitucional versus a Única Resposta Correta. Revista 
De fato, como destaca Neil MacCormick, mesmo que haja uma só resposta correta na interpretação das normas, o problema é que não há como identificar se a decisão alcançada em um determinado caso reflete esta única resposta. $^{189}$

Cabe inteira razão a Marco Aurélio Greco quando este afirma que "o intérprete tem um dever de fidelidade ao texto, mas isto não significa que o resultado da interpretação seja algo meramente matemático ou lógico dedutivo". 190

Não há se negar, portanto, que dentro dos lindes lingüísticos do texto normativo exerce o intérprete uma função criativa, consistente em determinar qual dos sentidos possíveis do texto comporá a norma individual e concreta. ${ }^{191}$

Latino-Americana de Estudos Constitucionais, Belo Horizonte, n. 2, jul.-dez. 2003, p. 313.

189 MacCORMICK, Neil, Argumentação Jurídica e Teoria do Direito, 2006, p. 321. Ver também: GRAU, Eros Roberto, Ensaio e Discurso sobre a Interpretação/Aplicação do Direito, 2002, p. 100-102.

190 GRECO, Marco Aurélio. Planejamento Fiscal. São Paulo: Dialética, 2004. p. 377.

191 Leciona Paulo de Barros Carvalho: “A missão do exegeta dos textos jurídico-positivos, ainda que possa parecer facilitada pela eventual coincidência da mensagem prescritiva com a seqüência das fórmulas gráficas utilizadas pelo legislador (no direito escrito), oferece ingentes dificuldades, se a proposta for a de um exame mais sério e atilado. E, sendo o direito um objeto da cultura, invariavelmente penetrado por valores, teremos, de um lado, as estimativas, sempre cambiantes em função da ideologia de quem interpreta; de outro, os intrincados problemas que cercam a metalinguagem, também inçada de dúvidas sintáticas e de problemas de ordem semântica e pragmática.

Tudo isso, porém, não nos impede de declarar que conhecer o direito é, em última análise, compreendê-lo, interpretá-lo, construindo o conteúdo, sentido e alcance da comunicação legislada. Tal empresa, que nada tem de singela, como vimos, requer o envolvimento do exegeta com as proporções inteiras do todo sistemático, incursionando pelos escalões mais altos e de lá regressando com os vetores axiológicos ditados por juízos que chamamos de princípios" (CARVALHO, Paulo de Barros. Proposta de Modelo Interpretativo para o Direito Tributário. Revista de Direito Tributário, São Paulo, n. 70, 1995, p. 41-42). Para Eros Roberto Grau, "em síntese: a interpretação do direito tem caráter constitutivo - não, pois, meramente declaratório - e consiste na produção, pelo intérprete, a partir de textos normativos e dos fatos atinentes a um determinado caso, de normas jurídicas a serem ponderadas para a solução desse caso, mediante a definição de uma norma 
$\mathrm{O}$ reconhecimento de que a interpretação compreende uma função criativa ${ }^{192}$ não significa que o intérprete crie a norma do nada, ex nihilo. Como

de decisão. Interpretar/aplicar é da concreção [=concretizar] ao direito. Neste sentido, a interpretação/aplicação opera a inserção do direito na realidade; opera a mediação entre o caráter geral do texto normativo e sua aplicação particular; em outros termos, ainda: opera a sua inserção na vida. A interpretação/aplicação vai do universal ao particular, do transcendente ao contingente; opera a inserção das leis [=do direito] no mundo do ser [=mundo da vida]. Como ela se dá no quadro de uma situação determinada, expõe o enunciado semântico do texto no contexto histórico presente, não no contexto da redação do texto. Interpretar o direito é caminhar de um ponto a outro, do universal ao particular, conferindo a carga de contingencialidade que faltava para tornar plenamente contingencial o particular" (GRAU, Eros Roberto. A Ordem Econômica na Constituição de 1988. 11. ed. São Paulo: Malheiros, 2006. p. 163).

192 É pertinente transcrever a lição de Luís Roberto Barroso que, embora voltada para a interpretação constitucional, a este campo não se restringe: “A moderna interpretação constitucional diferencia-se da tradicional em razão de alguns fatores: a norma, como relato puramente abstrato, já não desfruta de primazia; o problema, a questão tópica a ser resolvida passa a fornecer elementos para a sua solução; o papel do intérprete deixa de ser de pura aplicação da normas preexistente e passa a incluir uma parcela de criação do Direito do caso concreto. E, como técnica de raciocínio e de decisão, a ponderação passa a conviver com a subsunção. Para que se legitimem suas escolhas, o intérprete terá de servir-se dos elementos da teoria da argumentação, para convencer os destinatários do seu trabalho de que produziu a solução constitucionalmente adequada para a questão que lhe foi submetida. [...]" (BARROSO, Luís Roberto. Colisão entre Liberdade de Expressão e Direitos da Personalidade. Critérios de Ponderação. Interpretação Constitucional adequada do Código Civil e da Lei de Imprensa. In: PEIXINHO, Manoel Messias; GUERRA, Isabella Franco; NASCIMENTO FILHO, Firly (Orgs.). Os Princípios da Constituição de 1988. 2. ed. Rio de Janeiro: Lumen Juris, 2006. p. 258-259). Sobre a função criativa da interpretação, ver: RECASÉNS SICHES, Luis. Nueva Filosofia de la Interpretacion del Derecho. México: Editorial Porrua, 1980. p. 211-213; COSSIO, Carlos. El Derecho em el Derecho Judicial. Las Lagunas del Derecho. La Valoración Judicial. Buenos Aires: Librería El Foro, 2002. p. 121-122; TORRES, Ricardo Lobo, Normas de Interpretação e Integração do Direito Tributário, 2006, p. 45; LATORRE, Angel, Introdução ao Direito, 2002, p. 109-111; GRAU, Eros Roberto, Ensaio sobre a Interpretação/ Aplicação do Direito, 2002, p. 73-75; STRECK, Lenio Luiz, Hermenêutica Jurídica e $(m)$ crise: uma exploração hermenêutica da constituição do direito, 2003, p. 91-92; SCHROTH, Ulrich. Hermenêutica Filosófica e Jurídica. In: KAUFMANN, A.; HASSMER, N. (Orgs.). Introdução à Filosofia do Direito e à 
afirma Eros Roberto Grau, “o produto da interpretação é a norma expressada como tal. Mas ela (a norma) parcialmente preexiste, potencialmente, no invólucro do texto, invólucro do enunciado". ${ }^{193}$

Portanto, o intérprete cria, mas não cria do nada nem tampouco tal tarefa deixa de ser pautada por limites constantes no próprio texto interpretado, nos valores e interesses em jogo, os quais afastam qualquer decisionismo.

A abertura da linguagem implica a necessidade de superação da lógica binária que tomou conta do processo de subsunção. ${ }^{194}$

Teoria do Direito Contemporâneas. Lisboa: Fundação Calouste Gulbenkian, 2002. p. 383-384; GADAMER, Hans-Georg, Verdade e Método: traços fundamentais de uma hermenêutica filosófica, 2003, p. 432-433; LARENZ, Karl, Metodologia da Ciência do Direito, 1997, p. 283-284; ROSS, Alf, Direito e Justiça, 2000, p. 139; RADBRUCH, Gustav, Filosofia do Direito, 1997, p. 230-231; TÔRRES, Heleno Taveira. Interpretação e Integração das Normas Tributárias - Reflexões e Críticas. In: TÔRRES, Heleno Taveira (Coord.). Tratado de Direito Constitucional Tributário: Estudos em Homenagem a Paulo de Barros Carvalho. São Paulo: Saraiva, 2005. p. 112; CARDOZO, Benjamin N. The Nature of the Judicial Process. New Haven: Yale University Press, 1991. p. 112-115; ABRAHAM, Marcus, O Planejamento Tributário e o Direito Privado, 2007, 118-119.

193 GRAU, Eros Roberto, Ensaio sobre a Interpretação/Aplicação do Direito, 2002, p. 72-73.

194 Marco Aurélio Greco destaca a dificuldade de interpretar o direito com base no instrumental da lógica binária, em longa passagem a seguir transcrita: "Esta dificuldade enfrentada pela doutrina tem sua origem na premissa de que seria possível reconduzir roda realidade sempre a duas categorias opostas e, por conseqüência, a interpretação deveria orientar-se no sentido de identificar a qual delas pertenceria o objeto. Esta idéia de interpretar a realidade, inclusive jurídica, a partir de categorias opostas (lícito/ilícito; direito interno/internacional; vigência/ não-vigência; tributo/não-tributo, etc.) retrata um modelo de compreensão do mundo apoiado numa lógica bivalente que, em última análise, encontra sua origem no princípio da não-contradição formulado por Aristóteles. Admitida a idéia de uma lógica bivalente é, então, possível criar uma tabela de verdade das afirmações feitas sobre a realidade. De fato, se algo não pode ser e não ser ao mesmo tempo, determinada conduta, se for lícita, não será ao mesmo tempo ilícita, e assim por diante.

Ocorre que esta visão bivalente está passando por uma profunda revisão. Todo modelo teórico de compreensão da realidade implica uma simplificação do objeto para fins de permitir seu exame, a partir de elementos que constituiriam seu núcleo essencial. Esta lógica bivalente (sim/não; certo/errado; 0/1 etc.) 
Como salienta Marco Aurélio Greco, a lógica difusa (lógica fuzzy) seria a mais adequada para tratar com a indeterminação da linguagem, posição também defendida por Arthur Kaufmann. ${ }^{195}$

Ao descrever o funcionamento da lógica fuzzy, Susan Haack explica que o mesmo se dá aplicando-se variáveis fuzzy a conceitos não-fuzzy. ${ }^{196}$

Tomando por exemplo o significante verdade, partindo da lógica clássica bivalente trabalharíamos com as noções de verdadeiro/falso. Já a lógica fuzzy trabalha com as noções de muito falso, pouco falso, falso, pouco verdadeiro, muito verdadeiro, etc. ${ }^{197}$ Tal é exatamente a realidade da interpretação jurídica, onde, como destaca Arthur Kaufmann, "não há uma única solução correta, mas muitas soluções 'corretas', isto é, soluções 'defensáveis', plausíveis, suscetíveis de consenso". 198

Em um cenário como o descrito acima, temos que o relevante é a justificação, é que a decisão alcançada possa ser justificada de forma a ser aceita como a decisão do caso em disputa, sem que se afirme, com isso, que a decisão correta foi proferida.

São interessantes aqui as colocações de Dworkin sobre a justificação,

está se demonstrando insuficiente ou inadequada para explicar a realidade por corresponder a uma simplificação exagerada de um mundo complexo (simplificação, portanto, irreal).

Aliás, inúmeras são as dificuldades que uma lógica bivalente traz ao intérprete do ordenamento jurídico positivo (ou seu aplicador) que pretenda utilizá-la rigorosa e cegamente diante de uma situação concreta. Basta lembrar que, se a experiência jurídica se resumisse a uma lógica formal redutível a padrões absolutos de verdade, não existiria uma quantidade tão elevada de divergências e litígios.

Atualmente, estão em andamento vários estudos teóricos que partem de uma lógica não-bivalente e que se reúnem no conjunto que se convencionou denominar de "lógicas deviantes" a que pertence o sistema de lógica fuzzy, particularmente adequado para explicar a experiência jurídica, pois ela parte da idéia da imprecisão da linguagem e de que - por isso - os conceitos sempre apresentam certa margem de vaguedade" (GRECO, Marco Aurélio. Planejamento Tributário. São Paulo: Dialética, 2004. p. 374-375).

195 KAUFMANN, Arthur, Filosofia del Derecho, 1999, p. 82.

196 HAACK, Susan. Deviant Logic. Fuzzy Logic. Chicago: The University of Chicago Press, 1996. p. 234.

197 Cf. HAACK, Susan. Filosofia das Lógicas. Tradução Cezar Augusto Mortari; Luiz Henrique de Araújo Dutra. São Paulo: Editora UNESP, 2002. p. 222223.

198 KAUFMANN, Arthur, Filosofia del Derecho, 1999, p. 82. 
quando este afirma que a mesma tem duas dimensões: uma primeira, segundo a qual uma justificação deve ao menos de modo geral servir para suportar o que se pretende justificar. A título de exemplo, ensina Dworkin que atualmente uma justificação de caráter teológico não seria bastante para sustentar uma decisão. A segunda dimensão implica que a justificação deve se sustentar sobre algum valor suficientemente importante que a decisão venha proteger. ${ }^{199}$

Cresce, nessa assentada, a importância dos valores e dos princípios, os quais aparecem como instrumentos de justificação de decisões, até mesmo para que em um determinado caso concreto opte-se pela interpretação menos óbvia de acordo com a literalidade de um texto em detrimento da interpretação literal mais óbvia.

A atividade hermenêutica, portanto, se desenvolve nos marcos do pluralismo metodológico, ${ }^{200}$ não havendo fórmulas que garantam a correção na interpretação de textos normativos. ${ }^{201}$ Nessa perspectiva, os elementos de interpretação devem ser vistos como pontos de partida, tópicos a serem utilizados no processo hermenêutico. ${ }^{202}$

Ora, vê-se portanto que o problema hermenêutico atual, como pontuado acima, é de argumentação, participação e justificação. Diante da pluralidade de decisões possíveis muitas vezes presentes, a legitimidade da norma individual e concreta criada diante de dado caso dependerá exatamente do seu processo de criação.

Daí a grande relevância dos órgãos de aplicação do direito, responsáveis pela criação das normas individuais e concretas, principalmente,

199 DWORKIN, Ronald. Justice in Robes. Cambridge: Harvard University Press, 2006. p. 15.

200 Cf. TORRES, Ricardo Lobo, Normas de Interpretação e Integração do Direito Tributário, 2006, p. 153-154; COELHO, L. Fernando, Lógica Jurídica e Interpretação das Leis, 1981, p. 203-204; ABRAHAM, Marcus, O Planejamento Tributário e o Direito Privado, 2007, 124-125.

201 Ver: AFTALIÓN, Enrique R.; OLANO, Fernando García; VILANOVA, José, Introducción al Derecho, [196-], p. 453.

202 Como destaca Recaséns Siches, "o verdadeiro núcleo da função judicial não se radica, nem remotamente, o silogismo que se possa formular, mas sim consiste na eleição de premissas, por parte do juiz. Uma vez eleitas as premissas, a mecânica silogística funcionará com toda facilidade" (RECASÉNS SICHES, Luis, Nueva Filosofia de la Interpretacion del Derecho, 1980, p. 237). 
em um sistema de jurisdição una como o brasileiro, ${ }^{203}$ do Poder Judiciário, em cujo âmbito as atividades de argumentação, participação e justificação se realizam.

Nesta assentada se reafirma a impossibilidade de separação dos momentos de interpretação e aplicação do direito.

De fato, toda interpretação é já aplicação, já que realizada no intérprete tendo em vista o texto normativo e os fatos da questão sob apreço, o que ressalta a importância dos órgãos de aplicação no processo hermenêutico. ${ }^{204}$

\section{Referências Bibliográficas}

203 Sobre a jurisdição una pátria, ver: ROCHA, Sergio André. Processo Administrativo Fiscal: Controle Administrativo do Lançamento Tributário. 2. ed. Rio de Janeiro: Lumen Juris, 2007. p. 102-104.

204 Nas palavras de Castanheira Neves: "O centro metodologicamente referente está, pois, no juizo e não diretamente na norma - a norma será convocada, na sua normatividade, em função da problemática normativo-jurídica do juízo decisório, i. é, convocada pelas possibilidades que a sua normatividade ofereça como critério normativo-jurídico para uma normatividade fundada e problematicamente adequada - e assim com normativo-jurídica justeza - decisão judicativa. O pensamento jurídico de orientação tradicionalmente hermenêutica via o prius metodológico na norma, a determinar, por isso mesmo, em termos hermenêuticamente autônomos: interpretada primeiro a norma na sua autonomia abstrata, antes e independentemente da sua referência à decisão do caso concreto, seria ela depois 'aplicada' ao caso com o sentido ou a significação daquele modo determinados, sem consideração das exigências justificativas emergentes do problema do caso decidendo. Eram assim a 'interpretação' e a 'aplicação' atos metodologicamente de todo diferentes e autônomos. Pelo contrário, deverá reconhecer-se que o juízo da realização concreta do direito, e pelas suas exigências normativo-decisórias, é que dá sentido, conexiona e assimila num processo intencional-metodologicamente unitário todos os elementos que nele concorrem daí que a determinação do sentido normativo-jurídico da norma apenas se consuma no juízo e pelo juízo, só no juízo e pelo juízo a sua normatividade, sempre de uma aberta indeterminação em abstrato, se vai concretamente determinando. A 'interpretação' e a 'aplicação' não podem, pois, separar-se, antes se conjugam numa indissolúvel unidade - melhor, essa distinção deixa de ter sentido num processo que refere a norma, desde o princípio, em função do problema judicativodecisório e realiza o juízo mediante as possibilidades de critério que para ele ofereça a normatividade da norma" (NEVES, A. Castanheira. O Actual Problema Metodológico da Interpretação Jurídica - I. Coimbra: Coimbra Editora, 2003. p. 344-345). 
AARNIO, Aulis. La Tesis de la Única Respuesta Correcta y el Principio Regulativo del Razonamiento Jurídico. Doxa. Cuadernos de Filosofía del Derecho, Alicante, n. 8, 1990, p. 23-38;

. Sobre la Ambigüedad Semántica en la Interpretación Jurídica. Doxa. Cuadernos de Filosofía del Derecho, Alicante, n. 4, 1987, p. 109-117;

ABRAHAM, Marcus. O Planejamento Tributário e o Direito Privado. São Paulo: Quartier Latin, 2007. p. 96).

ADEODATO, João Maurício. Positividade e Conceito de Direito. In: Ética e Retórica: Para uma Teoria da Dogmática Jurídica. São Paulo: Saraiva, 2002.

AFTALIÓN, Enrique R.; OLANO, Fernando García; VILANOVA, José. Introducción al Derecho. 7. ed. Buenos Aires: La Ley, [196-].

ALCHOURRÓN, Carlos E. Introducción a la Metodología de las Ciencias Jurídicas y Sociales. Buenos Aires: Editorial Astrea, 2002

ALEXY, Robert. Teoria da Argumentação: A Teoria do Discurso Racional como Teoria da Justificação Jurídica. Tradução de Zilda Hutchinson Schild Silva. São Paulo: Landy, 2001.

Teoria de los Derechos Fundamentales. Tradução Ernesto Garzón Valdés. Madrid: Centro de Estudios Políticos y Constitucionales, 2001.

AMATUCCI,Andrea. La Interpretación de la Ley Tributaria. In: AMATUCCI, Andrea (Org.). Tratado de Derecho Tributario. Bogotá: Themis, 2001.

ANDRADE, José Maria Arruda de. Interpretação da Norma Tributária. São Paulo: MP Editora, 2006.

ATIENZA, Manuel. As Razões do Direito: Teorias da Argumentação Jurídica. Tradução Maria Cristina Guimarães Cupertino. São Paulo: Landy, 2002.

El Sentido del Derecho. 2. ed. Barcelona: Ariel, 2003. 
AUSTIN, John. The Province of Jurisprudence Determined. New York: Prometheus Books, [s/d].

ÁVILA, Humberto. Sistema Constitucional Tributário. São Paulo: Saraiva, 2004.

- Teoria dos Princípios: da definição à aplicação dos princípios jurídicos. São Paulo: Malheiros, 2003.

ÁYNEZ, Eduardo García. Introducción al Estudio del Derecho, 2002, p. 319;

BARCELLOS, Ana Paula de. Alguns Parâmetros Normativos para a Ponderação Constitucional. In: BARROSO, Luís Roberto (Org.). A Nova Interpretação Constitucional: Ponderação, Direitos Fundamentais e Relações Privadas. Rio de Janeiro/São Paulo: Renovar, 2003.

Janeiro: Renovar, 2005.

. Ponderação, Racionalidade e Atividade Jurisdicional. Rio de

BARRAGÁN, Julia. La Respuesta Correcta Única y la Justificación de la Decisión Jurídica. Doxa. Cuadernos de Filosofía del Derecho, Alicante, $n$. 8, 1990, p. 64-74;

BARROSO, Luís Roberto. O Começo da História. Nova Interpretação Constitucional e o Papel dos Princípios no Direito Brasileiro. In: BARROSO, Luís Roberto (Org.). A Nova Interpretação Constitucional: Ponderação, Direitos Fundamentais e Relações Privadas. Rio de Janeiro/São Paulo: Renovar, 2003.

BASTOS, Celso Ribeiro. Hermenêutica e Interpretação Constitucional. 2. ed. São Paulo: Celso Bastos Editor, 1999.

GRECO, Marco Aurélio. Planejamento Fiscal e Interpretação da Lei Tributária. São Paulo: Dialética, 1998.

BENTHAM, Jeremy. The Principles of Morals and Legislation. New York: Prometheus Books, [s/d].

BERGEL, Jean-Louis. Teoria Geral do Direito. Tradução Maria Ermantina 
Galvão. São Paulo, Martins Fontes, 2001.

BEVILAQUA, Clovis. Teoria Geral do Direito Civil. Rio de Janeiro: Editora Rio, 1975.

BILLIER, Jean-Cassien; MARYIOLI, Aglaé. História da Filosofia do Direito. Barueri: Manole, 2005.

BITTAR, Eduardo C. B. Hans-Georg Gadamer: a experiência hermenêutica e a experiência jurídica. In: BOUCAULT, Carlos E. de Abreu; RODRIGUEZ, José Rodrigo. Hermenêutica Plural. São Paulo: Martins Fontes, 2002.

BLEICHER, Josef. Hermenêutica Contemporânea. Tradução Maria Georgina Segurado. Lisboa: Edições 70, [s/d]. p. 161.

BOBBIO, Norberto. O Positivismo Jurídico: Lições de Filosofia do Direito. Tradução Márcio Pugliesi; Edson Bini; Carlos E. Rodrigues. São Paulo: Ícone, 1995.

BONAVIDES, Paulo. Curso de Direito Constitucional. 13. ed. São Paulo: Malheiros, 2003.

BONNECASE, Julien. Science du Droit et Romantisme. Paris: Librarie du Recueil Sirey, 1928. p. 9-13.

BUSTAMANTE, Thomas da Rosa de. Tópica e argumentação jurídica. Revista de Informação Legislativa, Brasília, n. 163, jul.-set. 2004, p. 154155 .

CALSAMIGLIA, Albert. ¿Por que es Importante Dworkin? Doxa. Cuadernos de Filosofía del Derecho, Alicante, n. 2, 1985, p. 159-161.

. Postpositivismo. Doxa. Cuadernos de Filosofía del Derecho, Alicante, n. 21, 1998, p. 209,

CAMARGO, Maria Margarida Lacombe, Hermenêutica Jurídica e Argumentação: Uma Contribuição ao Estudo do Direito, 2001.

. Eficácia Constitucional: Uma Questão Hermenêutica. In: 
BOUCALT, Carlos E. de Abreu;

CANARIS, Claus-Wilhelm. Pensamento Sistemático e Conceito de Sistema na Ciência do Direito. 2.ed. Tradução A. Menezes Cordeiro. Lisboa: Fundação Calouste Gulbenkian, 1996.

CANOTILHO, J. J. Gomes. Direito Constitucional e Teoria da Constituição. 3. ed. Coimbra: Almedina, [s/d]

CARDOZO, Benjamin N. The Nature of the Judicial Process. New Haven: Yale University Press, 1991.

CARRIÓ, Genaro R. Notas sobre Derecho y Lenguage. 4. ed. Buenos Aires: Abeledo-Perrot, 1994.

CARVALHO, Paulo de Barros. Curso de Direito Tributário. 15. ed. São Paulo: Saraiva, 2003.

. Proposta de Modelo Interpretativo para o Direito Tributário. Revista de Direito Tributário, São Paulo, n. 70, 1995.

COELHO, Fábio Ulhoa. Para Entender Kelsen. 4. ed. São Paulo: Saraiva, 2001.

COELHO, L. Fernando. Lógica Jurídica e Interpretação das Leis. 2. ed. Rio de Janeiro: Forense, 1981.

COING, Helmut, Elementos Fundamentais da Filosofia do Direito, 2002

COING, Helmut. Elementos Fundamentais da Filosofia do Direito. Tradução Elisete Antoniuk. Porto Alegre: Sergio Antonio Fabris, 2002.

COSSIO, Carlos. El Derecho em el Derecho Judicial. Las Lagunas del Derecho. La Valoración Judicial. Buenos Aires: Librería El Foro, 2002.

CRETTON, Ricardo Aziz. Os Princípios da Proporcionalidade e da Razoabilidade e sua Aplicação no Direito Tributário. Rio de Janeiro: Lúmen Júris, 2001. 
CRISTÓVAM, José Sérgio da Silva. Colisões entre Princípios Constitucionais. Curitiba: Juruá: 2006.

CUNHA, José Ricardo. Fundamentos Axiológicos da Hermenêutica Jurídica. In: BOUCAULT, Carlos E. de Abreu; RODRIGUEZ, José Rodrigo. Hermenêutica Plural. São Paulo: Martins Fontes, 2002. p. 321.

DANTAS, Ivo. Princípios Constitucionais e Interpretação Constitucional. Rio de Janeiro: Lúmen Júris, 1995.

DEL VECCHIO, Giorgio. Filosofia del Derecho. 9. ed. Barcelona: Bosch, 1997.

DINIZ, Maria Helena. Compêndio de Introdução à Ciência do Direito. 5. ed. São Paulo: Saraiva, 1993.

DWORKIN, Ronald. Justice in Robes. Cambridge: Harvard University Press, 2006.

. Law's Empire. Cambridge: Harvard University Press, 1999.

Press, 1999.

. Taking Rights Seriously. Cambridge: Harvard University

ENGELMANN, Wilson. Direito Natural, Ética e Hermenêutica. Porto Alegre: Livraria do Advogado, 2006.

ESPÍNOLA, Eduardo. Sistema de Direito Civil. Rio de Janeiro: Editora Rio, 1977.

FARALLI, Carla. A Filosofia Contemporânea do Direito: Temas e Desafios. Tradução Candice Premaor Gullo. São Paulo: Martins Fontes, 2006.

FERAZ JR., Tercio Sampaio. Introdução ao Estudo do Direito. 3. ed. São Paulo: Atlas, 2001.

FERNÁNDEZ-LARGO, Antonio Osuna. La Hermenéutica Jurídica de Hans-Georg Gadamer. Valladolid: Secretariado de Publicaciones, 1992. 
FERRARA, Francesco. Interpretação e Aplicação das Leis. 4. ed. Coimbra: Armênio Amado, 1987.

FRANÇA, Limongi. Hermenêutica Jurídica. 7. ed. São Paulo: Saraiva, 1999.

FREITAS, Juarez. A Melhor Interpretação Constitucional versus a Única Resposta Correta. Revista Latino-Americana de Estudos Constitucionais, Belo Horizonte, n. 2, jul.-dez. 2003.

GADAMER, Hans-Georg, O problema da consciência histórica, 1998, p. 57. . Verdade e Método II. 2. ed. Petrópolis: Vozes, 2004.

. Verdade e Método: traços fundamentais de uma hermenêutica filosófica, 2003.

. Gadamer in Conversation. Tradução de Richard Palmer. New Haven/London: Yale University Press, 2001.

. Homem e Linguagem. In: Verdade e Método II. 2. ed. Petrópolis: Vozes, 2004.

. La Diversidade de las Lenguas y la Comprensión del Mundo. In: Arte y Verdad de la Palabra. Tradução José Francisco Zuñiga García. Barcelona: Paidós, 1998. p. 119.

. La hermenêutica y la escuela de Dilthey. In: El Giro Hermenéutico. Tradução Arturo Parada. Madrid: Ediciones Cátedra, 1995. p. 146.

GARCÍA AMADO, Juan Antonio. Tópica, Derecho y Método Jurídico. Doxa. Cuadernos de Filosofía del Derecho, Alicante, n. 4, 1987.

GARCÍA MÁYNEZ, Eduardo. Introducción al Estudio del Derecho. 53. ed. México: Editorial Porrúa, 2002.

GÉNY, François. Método de Interpretación y Fuentes em Derecho Privado Positivo. Madrid: Editorial Réus, 1925. 
GRAU, Eros Roberto. O direito posto e o direito pressuposto. 3. ed. São Paulo: Malheiros, 2000.

. A Ordem Econômica na Constituição de 1988. 11. ed. São Paulo: Malheiros, 2006. p. 163).

. Ensaio e Discurso sobre a Interpretação/Aplicação do Direito. São Paulo: Malheiros, 2002.

GRECO, Marco Aurélio. Planejamento Tributário. São Paulo: Dialética, 2004.

GREEN, Michael Steven. Legal Realism as Theory of Law. William and Mary Law Review, Williamsburg, n. 46, abr. 2005.

GUASTINI, Ricardo. Das Fontes às Normas. Tradução Edson Bini. São Paulo: Quartier Latin, 2005.

GUASTINI, Ricardo. Teoria e Dogmatica delle Fonti. Milano: Giuffrè, 1998.

GUERRA FILHO, Willis Santiago. Teoria da Ciência Jurídica. São Paulo: Saraiva, 2001.

GÜNTHER, Klaus. Teoria da Argumentação no Direito e na Moral: Justificação e Aplicação. Traducão Cláudio Molz. São Paulo: Landy, 2004.

GUSMÃO, Paulo Dourado de. Introdução ao Estudo do Direito. 26. ed. Rio de Janeiro: Forense, 1999

HAACK, Susan. Deviant Logic. Fuzzy Logic. Chicago: The University of Chicago Press, 1996.

HAACK, Susan. Filosofia das Lógicas. Tradução Cezar Augusto Mortari; Luiz Henrique de Araújo Dutra. São Paulo: Editora UNESP, 2002.

HART, H. L. A. Essays in Jurisprudence and Philosophy. New York: Oxford University Press, 2001. . The Concept of Law. 2nd. ed. New York: Oxford University Press, 
1997.

HECK, Philipp. El Problema de la Creación del Derecho. Tradução Manuel Entenza. Granada: Comares, 1999.

HESPANHA, António Manuel, Cultura Jurídica Européia: Síntese de um Milénio, 2003, p. 289; KLUG, Ulrich. Lógica Jurídica. Tradução J. C. Gardella. Bogotá: Themis, 2004. p. 11-12.

HESPANHA, António Manuel, Cultura Jurídica Européia: Síntese de um Milénio, 2003,

HESSE, Konrad. Elementos de Direito Constitucional da República Federal da Alemanha. Tradução Luís Afonso Heck. Porto Alegre: Sergio Antonio Fabris, 1998. p. 61 e 62

IHERING, Rudolf von. El Fin en el Derecho. Tradução Leonardo Rodriguez. Panplona: Analecta Editorial, 2005. p. 8

JAPIASSÚ, Hilton; MARCONDES, Danilo. Dicionário Básico de Filosofia. 3. ed. Rio de Janeiro: Jorge Zahar Editor, 1996.

JESUS, Damásio E. de. Direito Penal. 19. ed. São Paulo: Saraiva, 1995. v. I.

KAUFMANN, Arthur. A problemática da filosofia do direito ao longo da história. In: KAUFMANN, Arthur; ACEDER, W. (Ufrgs.). Introdução à Filosofia do Direito e à Teoria do Direito Contemporâneas. Tradução Marcos Keel. Lisboa: Fundação Calouste Gulbenkian, 2002.

. Filosofía del Derecho. Tradução Luis Villar Borda. Bogotá: Universidad Externado de Colombia, 1999.

KELSEN, Hans. O Problema da Justiça. Tradução João Baptista Machado. São Paulo: Martins Fontes, 1998.

. Teoria Pura do Direito. 6. ed. Tradução João Baptista Machado. Coimbra: Armenio Amado, 1984.

LARENZ, Karl. El Derecho Justo. Tradução Luis Díes-Picazo. Madrid: 
Civitas, 2001.

. La Filosofía Contemporánea del Derecho y del Estado. Tradução E. Galán Gutiérrez; A. Truyol Serra. Madrid: Editorial Revista de Derecho Privado, 1942. p. 98.

. Metodologia da Ciência do Direito. 3.ed. Tradução José Lamego. Lisboa: Fundação Calouste Gulbenkian, 1997.

LATORRE, Angel. Introdução ao Direito. Tradução Manuel de Alarcão. Coimbra: Almedina, 2002.

LEAL, Rogério Gesta. Perspectivas Hermenêuticas dos Direitos Fundamentais no Brasil. Porto Alegre: Livraria do Advogado, 2000.

LEITER, Brian R, American Legal Realism. In: The Blackwell Guide to Philosophy of Law and Legal Theory. Oxford: Blackwell, 2003. Disponível em SSRN: http://ssrn.com/abstract=339562. Acesso em 21 de fevereiro de 2006;

LINGE, David E. [Introduction to Gadamer's Philosofical Hermeneutics]. In: GADAMER, Hans-Georg. Philosofical Hermeneutics. Tradução David E. Linge. Berkeley/Los Angeles/London: University of California Press, 1997.

LOPES, Miguel Maria de Serpa. Curso de Direito Civil. 7. ed. Rio de Janeiro: Freitas Bastos, 1989. v. I.

MacCORMICK, Neil, Argumentação Jurídica e Teoria do Direito, 2006, p. 321. Ver também: GRAU, Eros Roberto, Ensaio e Discurso sobre a Interpretação/Aplicação do Direito, 2002.

MAIA, Antônio Cavalcanti. A importância da dimensão argumentativa à compreensão da práxis contemporânea. Revista Trimestral de Direito Civil, Rio de Janeiro, v. 8, out.-dez. 2000.

MAXIMILIANO, Carlos. Hermenêutica e Aplicação do Direito. 18. ed. Rio de Janeiro: Forense, 1999. 
MENDONÇA. Paulo Roberto Soares de. A Tópica e o Supremo Tribunal Federal. Rio de Janeiro: Renovar, 2003.

MIRABETE, Julio Fabrini. Manual de Direito Penal. São Paulo: Atlas, 1998. v. I.

MORRISON, Wayne. Filosofia do Direito: Dos Gregos ao Pós-modernismo. Tradução Jefferson Luiz Camargo. São Paulo: Martins Fontes, 2006.

MÜLLER, Friedrich. Métodos de Trabalho do Direito Constitucional. 3. ed. Rio de Janeiro: Renovar, 2005.

NASCIMENTO FILHO, Firly (Orgs.). Os Princípios da Constituição de 1988. 2. ed. Rio de Janeiro: Lumen Juris, 2006

NEDEL, Antônio. Uma Tópica Jurídica: clareira para a emergência do direito. Porto Alegre: Livraria do Advogado, 2006.

NEVES, A. Castanheira. Metodologia Jurídica: Problemas Fundamentais. Coimbra: Coimbra Editora, 1993.

. O Actual Problema Metodológico da Interpretação Jurídica - I. Coimbra: Coimbra Editora, 2003.

OLIVEIRA ASCENÇÃO, José de. Introdução à Ciência do Direito. 3. ed. Rio de Janeiro: Renovar, 2005.

OULMIN, Stephen. Os Usos do Argumento. Tradução Reinaldo Guarany. São Paulo: Martins Fontes, 2001.

PALMER, Richard. Hermeneutics. Evanston: Northwestern University Press, 1969.

PECES-BARBA, Gregório; FERNÁNDEZ, Eusébio; ASÍS, Rafael. Curso de Teoría del Derecho. 2. ed. Madrid: Marcial Pons, 2000. p. 232;

PEREIRA, Caio Mário da Silva. Instituições de Direito Civil. 11. ed. Rio de Janeiro: Forense, 1989. v. I. 
PERELMAN, Chaïm. Ética e Direito. Tradução Maria Emantina Galvão. São Paulo: Martins Fontes, 2002.

Martins Fontes, 2000.

. Lógica Jurídica. Tradução Vergínia K. Pupi. São Paulo: OLBRECHTS-TYTECA, Lucie. Tratado da Argumentação. Tradução Maria Ermantina Galvão. São Paulo: Martins Fontes, 2000.

RADBRUCH, Gustav. Filosofia do Direito. 6. ed. Tradução L. Cabral de Moncada. Coimbra: Arménio Amado, 1997.

RÁO, Vicente. O Direito e a Vida dos Direitos. 5. ed. São Paulo: Revista dos Tribunais, 1999. p. 514.

RAWLS, John. A Theory of Justice. Cambridge: Harvard University Press, 2001.

RAZ, Joseph. ¿Por Qué Interpretar? Isonomía, México, n. 5, Out.-1996.

REALE, Miguel. Filosofia do Direito. 19. ed. São Paulo: Saraiva, 2002.

RECASÉNS SICHES, Luis. Nueva Filosofia de la Interpretacion del Derecho. México: Editorial Porrua, 1980.

México: Porrua, 1963. t. I.

. Panorama del Pensamiento Jurídico en el Siglo XX.

. Tratado General de Filosofía del Derecho. 14. ed. México: Editorial Porrúa, 1999.

RICOEUR, Paul. Hermeneutics \& the Human Sciencies. Tradução de John B. Thompson. Cambridge: Cambridge University Press, 1998.

ROBLES, Gregorio. Introducción a la teoría del derecho. 6. ed. Barcelona: Debate, 2003.

ROCHA, Sergio André. Processo Administrativo Fiscal: Controle Administrativo do Lançamento Tributário. 2. ed. Rio de Janeiro: Lumen 
Juris, 2007.

RODRIGUES, Silvio. Direito Civil. 20. ed. São Paulo: Saraiva, 1989. v. I.

RODRIGUEZ , José Rodrigo (Coords.). Hermenêutica Plural. São Paulo: Martins Fontes, 2002.

ROHDEN, Luiz. Hermenêutica Filosófica. São Leopoldo: Editora Unisinos, 2002.

ROSS, Alf. Direito e Justiça. Tradução Edson Bini. Bauru: EDIPRO, 2000.

Towards a Realistic Jurisprudence. Tradução Annie I. Fausboll. [s/l]: Scientia Verlad Aalen, 1989.

SALDANHA, Nelson. Da Teologia à Metodologia: Secularização e crise do pensamento jurídico. 2. ed. Belo Horizonte: Del Rey, 2005.

SARMENTO, Daniel. A Ponderação de Interesses na Constituição Federal. Rio de Janeiro: Lumen Juris, 2002.

SAVIGNY, Friedrich Karl von. Sistema del Derecho Romano Actual. 2. ed. Tradução Jacinto Mesía; Manuel Poley. Madrid: Editorial de Góngora, [s/d]. t. I.

SCHROTH, Ulrich. Hermenêutica Filosófica e Jurídica. In: KAUFMANN, A.; HASSMER, N. (Orgs.). Introdução à Filosofia do Direito e à Teoria do Direito Contemporâneas. Lisboa: Fundação Calouste Gulbenkian, 2002.

SILVA, Kelly Susane Alflen da. Hermenêutica Jurídica e Concretização Judicial. Porto Alegre: Sergio Antonio Fabris Editor, 2000.

STRECK, Lenio Luiz. Hermenêutica Jurídica (em) Crise. Porto Alegre: Livraria do Advogado, 2003.

- A hermenêutica filosófica e as possibilidades de superação do positivismo pelo (neo)constitucionalismo. In: STRECK, Lenio Luiz; ROCHA, Leonel Severo (Orgs.). Constituição, Sistemas Sociais e Hermenêutica. Porto Alegre: Livraria do Advogado, 2005. p. 167. 
. Jurisdição Constitucional e Hermenêutica: Uma Nova Crítica do Direito. 2. ed. Rio de Janeiro: Forense, 2004. p. 32.

. O Efeito Vinculante das Súmulas e o Mito da Efetividade: Uma Crítica Hermenêutica. In: Crítica à Dogmática: Dos Bancos Acadêmicos à Prática dos Tribunais. Porto Alegre: Instituto de Hermenêutica Jurídica, 2005. p. 92;

- Verdade e Consenso: Constituição, Hermenêutica e Teorias Discursivas. Rio de Janeiro: Lumen Juris, 2006. p. 183-195.

STRUCHINER, Noel. Direito e Linguagem: Uma Análise da Textura Aberta da Linguagem e sua Aplicação ao Direito. Rio de Janeiro: Renovar, 2002.

TÔRRES, Heleno Taveira. Interpretação e Integração das Normas Tributárias - Reflexões e Críticas. In: TÔRRES, Heleno Taveira (Coord.). Tratado de Direito Constitucional Tributário: Estudos em Homenagem a Paulo de Barros Carvalho. São Paulo: Saraiva, 2005.

TORRES, Ricardo Lobo. Tratado de Direito Constitucional Financeiro e Tributário: Valores e Princípios Constitucionais Tributários. Rio de Janeiro: Renovar, 2005.

VATTIMO, Gianni. Introducción a Heidegger. Barcelona: Gedisa, 2002.

VIEHWEG, Theodor. Algunas Consideraciones acerca del Razonamiento Jurídico. In: Tópica y Filosofia del Derecho. Tradução Jorge M. Seña. Barcelona: Gedisa, 1997.

. Tópica e Jurisprudência. Tradução Tercio Sampaio Ferraz Jr. Brasília: Departamento de Imprensa Nacional, 1979.

WARAT, Luiz Alberto. Introdução Geral ao Direito. Porto Alegre: Sergio Antonio Fabris Editor, 1994. v. I. 